\begin{tabular}{|c|c|c|c|}
\hline $\begin{array}{l}\text { FATIH } \\
\text { SULTAN } \\
\text { MEHMET } \\
\text { VAKIF UNIVERSITESI } \\
2010\end{array}$ & $\begin{array}{r}\text { FS } \\
\text { FSM S }\end{array}$ & $\begin{array}{l}\text { M ilmî Araştırmalar Insan ve Toplum Bilimleri Dergisi } \\
\text { cholarly Studies Journal of Humanities and Social Sciences } \\
\text { Sayı/Number } 14 \text { Yıl/Year } 2019 \text { Güz/Autumn } \\
\text { C } 2019 \text { Fatih Sultan Mehmet Vakıf Üniversitesi }\end{array}$ & 口ifing \\
\hline DOI: & - & http://dergipark.org.tr/fsmia & http://dergi.fsm.edu.tr \\
\hline Araştırma Makalesi / Research Article & le - & Geliş Tarihi / Received: 27.03.2019 Kabul Tarihi / Accepted:08.07.2019 - FS & FSMIAD, 2019; (14): 151-194 \\
\hline
\end{tabular}

\title{
Vakfiyesi Işığında Şah Sultan ve Zal Mahmud Paşa Külliyesi \\ Betül Kahraman*
}

$\ddot{O} z$

Bu makalede Osmanlı medeniyetinin en önemli değerlerinden olan vakıflar'ın bir örneği olarak Şah Sultan ve Zal Mahmud Paşa Vakfı ele alınmıştır. 16. yüzyıl sonunda kurulan bu vakfın kurucuları II. Selim'in kızı Şah Sultan ile eşi Vezir Zal Mahmud Paşa’nın hayatı ve kurmuş oldukları vakıflar irdelenmiştir.

Anahtar Kelimeler: Osmanlı Vakıfları, Vakfiye, Şah Sultan ve Zal Mahmud Paşa.

\section{In the Light of Its Vaqfiyye, Şah Sultan and Zal Mahmud Pasha Complex}

\section{Abstract}

In this article, Şah Sultan and Zal Mahmud Pasha Charity was taken into consideration as an example of "Charities" which is one of the most important values of Ottoman Civilization. Life story of founders of charity who was the daughter of Selim II, Şah Sultan and her husband Vizier Zal Mahmud Pasha and information about their charities which where founded at the and of 16th Century, were stated.

Keywords: Ottoman Foundations, Vaqfiyye, Şah Sultan and Zal Mahmud Pasha.

* Yüksek Lisans Mezunu Öğrencisi, Fatih Sultan Mehmet Vakıf Üniversitesi Lisansüstü Eğitim Enstitüsü Tarih Anabilim Dalı, İstanbul/Türkiye, bkahraman@medipol.edu.tr, orcid.org/00000001-6966-3820 


\section{Şah Sultan ve Zal Mahmud Paşa}

\section{Şah Sultan'ın Hayatı}

Şah Sultan, II. Selim'in Nurbanu Sultan'dan olan kızıdır. II.Selim'in şehzadeliği sırasında 1546 yılında Manisa'da dünyaya gelmiştir. ${ }^{1} 1562$ yılında Kanuni Sultan Süleyman'ın, torunlarını evlendirmeye karar vermesiyle 16 yaşında ilk evliliğini gerçekleştirmiştir. Şehzade Selim ile Şehzade Bayezid'in mücadelesinde Selim'in üstünlüğünü sağlamada yararlılık gösteren Sokollu Mehmed Paşa İsmihan Sultan ile, Piyale Paşa Gevherhan Sultan ile, Şah Sultan ise Enderunî Çakırcı Hasan Ağa'yla nikahlanmıştır. ${ }^{2}$ Ancak, Çakırcı Hasan Paşa ile Şah Sultan'ın evliliklerinin çok uzun sürmediği anlaşılmaktadır. Tıpkı büyük halası Şah Huban Sultan'ın Lütfi Paşa'yı boşadığ ${ }^{3}$ gibi Şah Sultan da Hasan Paşa'dan boşanmıştır. Bu mutsuz evlilikten sonra kendisi Zal Mahmud Paşa ile evlendirilmiş ve hayatının sonuna kadar da onunla yaşamıştır. Zal Mahmud Paşa ile 1566 senesinde evlendirildiği göz önünde bulundurulduğunda Hasan Paşa ile olan evliliği en fazla üç sene sürmüş olmalıdır.

Şah Sultan'ın hayatı ile ilgili önemli bir husus ise 1572 y1lında hac vazifesini yapmış olmasıdır. İstanbul'dan ayrılan Şah Sultan'ın yolculuğunun güvenli bir şekilde sürmesi için Anadolu, Karaman, Halep, Şam beylerbeyleri ile Niğde ve Adana beylerine emirler yazılmış, Emir-i hacdan Şam ve Mekke arasındaki seyahatinin güvenliği için gerekli tedbirlerin alınması istenmiştir. ${ }^{4}$ Mühimme kayıtlarından Şah Sultan'ın Kudüs'e de ziyarette bulunduğu anlaşılmaktadır. ${ }^{5}$ O dönemde Şah Sultan'ın hac farizasını gerçekleştirmesi onun dindar bir şahsiyet olduğunu göstermektedir.

Peçuylu, Gelibolulu Âlî̀'den naklen Şah Sultan ve Zal Mahmud Paşa'nın aynı gün hastalanıp helalleşerek, kucaklaşıp birlikte vefat ettiklerini ve bu durumun onların birbirlerine olan sevgisine yorulduğunu yazmıştır. ${ }^{6}$ Karı kocanın ölüm yılı Çağatay Uluçay tarafından 1580 olarak verilmişse de, ${ }^{7}$ üzerinde çalıştığımız

1 Necdet Öztürk, “Kadızâde Vusûlî Mehmed Çelebi ve Selim-name'si”, Türk Dünyası Araştırmalarl, say1 50, İstanbul 1987, s. 36.

2 M. Çağatay Uluçay, Padişahların Kadınları ve Kızları, İstanbul, Ötüken, 2012, s.70.

3 Leslie P. Peirce, Harem-i Hümayun, Osmanlı Imparatorluğu'nda Hükümranlık ve Kadınlar, çev. Ayşe Berktay, İstanbul, Tarih Vakfı Yurt Yayınları, 2016, s. 278.

4 Mustafa Güler, "Şah Sultan ile Zal Mahmud Paşa Vakfiyesi”, Eyüp Sultan Sempozyumu V Tebliğler, İstanbul, Eyüp Belediyesi Kültür Yayınları, 2002, s. 210.

5 Muharrem Bostancı, "19 Numaralı Mühimme Defteri”, (Yayımlanmamış Yüksek Lisans Tezi), İstanbul Üniversitesi Sosyal Bilimler Enstitüsü, İstanbul 2002, s. 305.

6 Peçuylu İbrahim, Tarih-i Peçevi, I, 1281, s.446.

7 Uluçay, a.g.e, s.70. 
vakfiye metninde Şah Sultan'ın gerçek vefat tarihinin 5 Kasım 1577 (23 Şaban 985) olduğu anlaşılmaktadır. ${ }^{8} 31$ yaşında vefat eden genç sultanın cenaze merasimi, bir sefaret heyeti içerisinde yer alarak, İstanbul'a gelen protestan vaizi Stephan Gerlach'ın günlük şeklinde tuttuğu notlarında yer almaktadır. Vakfiyedeki tarih Gerlach'1n günlükleriyle tutarlılık göstermektedir. Zal Mahmud Paşa, Şah Sultan'dan 13 gün önce vefat etmiş olduğundan, yukarıda bahsettiğimiz Peçuylu'da yer alan aynı günde vefat etmeleri hadisesi doğru değildir. Ancak, bu bilgi vefat tarihleri arasında kısa zaman dilimi bulunduğunu yansıtmaktadır.

Öğle vaktinde yapılan Şah Sultan'ın cenaze merasimini, başkalarına kıyasla sönük bulan Gerlach töreni: "Tabutun baş kisminda kadınların taktıkları altın ve mücevherlerle süslü bir başlık, orta klsmında da dört parmak genişliğinde altın ve mücevherli bir kuşak vardl, her ikisi toplam birkaç bin duka değerindeydi. Tabutun her iki yanından ve arkasından kalabalık bir insan topluluğu yürüyordu. En arkadan Sokollu Mehmed Paşa, yaninda Rumeli kazaskeri olduğu halde, onun arkasindan da Mustafa Paşa, Ahmed Paşa, Sinan Paşa, Anadolu kazaskeri, Rumeli beylerbeyi, Yeniçeri ağası, at üstünde ve siyah giyisiler içinde cenazeyi takip ediyorlard. Yeniçeriler her zamanki başlıklarının yerine sarık takmışlardı." şeklinde anlatmıştır. ' Şah Sultan'ın cenazesi Eyüp'te inşası devam eden külliyesinin bahçesine eşi Zal Mahmud Paşa'nın yanına defnedilmiştir.

Şah Sultan, babası tarafından kendisine Filibe'de temlik edilen on dört köyün ${ }^{10}$ gelirleri ile bir vakıf kurmuş ve hanedanın diğer kadın üyeleri gibi hayır işlerinde bulunmuştur. Bu arada 1572 yılında eşi Zal Mahmud Paşa ile birlikte, Eyüp'te bir cami ve iki medrese inşa ettirmeye başlamış, vefatlarından sonra bir türbe ve çeşme ilave edilerek, külliye tamamlanmıştır.

\section{Şah Sultan'a Ait Vesikalar}

Şah Sultan ile ilgili elimize ulaşan arşiv malzemesi yok denecek kadar azdır. Bunun nedenlerinden biri şüphesiz ki Topkapı Sarayı'nda değil de taşrada Manisa ve Konya gibi şehzade sancaklarında yaşamış olmasıdır. Babası tahta çıktığında Zal Mahmud Paşa ile evli bulunması da bu süreci devam ettirmiş ve hayatı hakkında bilgi sahibi olabileceğimiz evraklar elimize geçmemiştir. Bugün, Şah Sultan ile ilgili elimize ulaşan üç farklı arşiv belgesi ile bir mühimme kaydı mevcuttur. Bunlardan biri Osmanlı Arşivi’nde yer alan Şah, Gevherhan

8 BOA, EV.VKF, 20/25, 29 Z 1002/15 Eylül 1594, vr.7a.

9 Stephan Gerlach, Türkiye Günlüğ̈̈, II, çev. Türkis Noyan, ed. Kemal Beydilli, İstanbul, Kitap Yayinevi, 2007, s. 668.

10 Tayyib Gökbilgin köy sayısı için on iki demiştir. Bkz. M. Tayyib Gökbilgin, XV. ve XVI. Asırlarda Edirne Ve Paşa Livası, Vakıflar-Mülkler-Mukataalar, İstanbul, İşaret Yayınları, 2007, s. 502. 
ve İsmihan Sultan'ın evlilik hazırlıkları ve çeyiz listesini içeren evraktır. İkincisi, Şah Sultan'ın Zal Mahmud Paşa ile evli iken bulunduğu yerde hastalık çıkmasından ötürü Mehmed Paşa çiftliğine getirilmesine dair TSMA evrak1, üçüncüsü de Şah Sultan'ın babası II. Selim'e yazmış olduğu hususi mektuptur. Mühimme Defteri'nde ise Sultan'ın hac yolculuğu ile ilgili taşra idarecilerine yazılmış emirler bulunmaktadır. Bunların Latin harflerine aktarılmış haline çalışmamızda yer vererek, Şah Sultan'a ait vesikaların bir arada olmasını uygun gördük.

İlk olarak ele alacağımız vesika, evlilik hazırlıkları ve çeyiz listesini içeren belgelerdir. Hanedandan kız almak sıradan bir olay olmadığı için çoğu zaman damatlara, masraflar ve hediyeleri karşılayabilmesi için hazineden para verilmekte idi. ${ }^{11}$ Bunun için Sokollu Mehmed Paşa'ya 15.000 filori, Piyale Paşa'ya 10.000 filori ve Çakırcı Hasan Paşa'ya ise 15.000 filori miktarında para ödenmiştir. Ayrıca sağdıç olan Ferhad Paşa, beylerbeyi ve büyük mirahura da toplamda 40.000 filori verilmiştir. ${ }^{12}$ Düğün için icap eden hilatler ve çeşitli kumaşlar için listeler tutulmuştur. Bunlardan sultanlar için lazım olacak bakır ${ }^{13}$ ve gümüş ${ }^{14}$ evaniye dair listeler de elimizde bulunmaktadır. Daha çok mutfak eşyaları içeren çeyiz listesi aşağıdadır.

Tablo 1: Üç Sultana Ait Çeyiz Listesi

\begin{tabular}{|c|l|c|}
\hline Malzeme & Cinsi & Adet \\
\hline Sahan kapağıyla & Bakır & 50 'şer \\
\hline Kuzin tepsi & Bakır & 5 'şer \\
\hline Yemiş tepsileri & Bakır & 30 'şer \\
\hline Ondan küçük tepsi & Bakır & 20 'şer \\
\hline Ondan dahi küçük tepsi & Bakır & 20 'şer \\
\hline Baklava tepsisi & Bakır & 10 'ar \\
\hline Hoşaf tası & Bakır & 5 'er \\
\hline Üskûr kapaklı & Bakır & 5 'er \\
\hline Küçük üskûrlar & Bakır & 10 'ar \\
\hline Şamdanlar & Bakır & 10 'ar \\
\hline
\end{tabular}

11 Uluçay, Harem, İstanbul, Ötüken, 2011, s. 171.

12 BOA, TSMA.d,7859.0003, 29 Z 969/30 Ağustos 1562.

13 BOA, TSMA.d,7859.0006, 29 Z 969/ 30 Ağustos 1562.

14 BOA, TSMA.d,7859.0005.00, 29 Z 969/30 Ağustos 1562. 


\begin{tabular}{|c|c|c|}
\hline Kuzin tavası & Bakır & 2'şer \\
\hline Kulplu değirmen tava & Bakır & 2'şer \\
\hline Sapli tava & Bakır & 2'şer \\
\hline Havan & Bakır & 2'şer \\
\hline Bakraçlar & Bakır & 2'şer \\
\hline Büyük maşrapa & Bakır & 5'er \\
\hline Küçük maşrapa & Bakir & 2'şer \\
\hline Al leğen ibriğiyle & Bakır & 6'şar \\
\hline Abdest leğen ibriğiyle & Bakır & 3'er \\
\hline İbrikler & Bakır & 10 'ar \\
\hline Hamam nalınları & Bakır & 3'er \\
\hline Tencereler Büyük & Bakır & 5'er \\
\hline Küçük tencereler & Bakır & 5'er \\
\hline Şamdan & Gümüş & 2'şer \\
\hline Al leğen ibrik & Gümüş & 2'şer \\
\hline Abdest leğeni ibrik & Gümüş & 1'er \\
\hline Hoşaf tası & Gümüş & 2'şer \\
\hline Hamam leğeni & Gümüş & 2'şer \\
\hline Hamam tas1 & Gümüş & 2'şer \\
\hline Şerbet üskûrlar & Gümüş & 5'er \\
\hline Turşu üskûrlar & Gümüş & 4'er \\
\hline Kuzin tepsi & Gümüş & 1'er \\
\hline Büyük tepsi & Gümüş & 5'er \\
\hline Küçük tepsi & Gümüş & 5'er \\
\hline Büyük maşrapa & Gümüş & 1 'er \\
\hline Küçük maşrapa & Gümüş & 3'er \\
\hline Tabak & Gümüş & 1'er \\
\hline
\end{tabular}

Yukarıda gösterilen mutfak ve hamam takımları dışında düğün için kapıağasına sipariş olunan kemer, istefan ve çeşitli kumaş ve mücevherler ile bunlar için ödenen filori miktarı aşağıda yer alan tabloda gösterilmektedir: 
Tablo 2: Düğün için sipariş olunan malzemeler ve fiyatları ${ }^{15}$

\begin{tabular}{|c|c|}
\hline Malzeme & Fiyat $^{16}$ \\
\hline Bir kemer & 1.200 \\
\hline Diğer kemer & 1.100 \\
\hline Diğer kemer & 600 \\
\hline Bir istefan & 3.000 \\
\hline Diğer istefan & 2.000 \\
\hline Diğer istefan & 1.050 \\
\hline Altı tane la'l yüzük & 566 \\
\hline Dört tahta la'l yüzük & 600 \\
\hline İki yüz kırk beş lülü & 5.125 \\
\hline Doksan yedi tane la'l & 13.139 \\
\hline Altmış pare donluk serâser altın & 3.130 \\
\hline Altmış beş tak Bursa ve Amasya & 312 \\
\hline Gazancıbaşına Avadanlık harcı & 37 \\
\hline İki yüz top astara & 160 \\
\hline Dört yüz yirmi zirâ' kadife & 1.244 \\
\hline Bazı bakır avadanlık harcına & 48 \\
\hline Bakır üskûreler & 13 \\
\hline Üç kıza ikişer bin filori & 6.000 \\
\hline On dokuz tak çatma ve iki tak serâser & 1.155 \\
\hline Bazı kumaş bahasına & 562 \\
\hline Dokuz tane zerbaft kuşak bahasına & 310 \\
\hline Elli tak serâser bahasına & 2.325 \\
\hline Bir istefân bahasına & 1.000 \\
\hline Altı yüz otuz altı kırât la 'l & 4.152 \\
\hline İki gümüş sini yaldızına & 12 \\
\hline Üç çift (...) ve bilezik bahasına & 2.500 \\
\hline On üç tak serâser bahasına & 600 \\
\hline
\end{tabular}

15 BOA, TSMA.d,7859.0002.00, 29 Z 969/ 30 Ağustos 1562.

16 Fiyatlar filori cinsindendir. 


\begin{tabular}{|c|c|}
\hline Lale ve pul harcı için kuyumcubaşına & 100 \\
\hline Taçlar harcı için kuyumcubaşına & 16 \\
\hline Altı tak duhavi kadife bahasına & 393 \\
\hline Bin zirâ' ${ }^{\prime 1}$ atlas & 1.333 \\
\hline Kırk bir (...) & 798 \\
\hline Def'a lale ve pul harcı için kuyumcubaşına & 100 \\
\hline Üç nerdbân ve iki kürsi yaldızına & 11 \\
\hline Dokuz sahan bahasına & 6 \\
\hline Elli altı tak serâser & 2.439 \\
\hline Hanımdan verilen pul ve lale harcına kuyumcubaşına & 154 \\
\hline Hanımlar için dikilen Mendil ve yasdık harcına & 1.214 \\
\hline Def' a kuyumcubaşına lale ve pul harcı için & 142 \\
\hline Gümüş avadanlık harcına gazancıbaşına & 16 \\
\hline Dokuz sahan kapağı ve iki baklava tepsi bahasına & 10 \\
\hline Def' a kuyumcubaşına lale ve pul harcı için & 15 \\
\hline Taçlar için (...) bahasına & 10 \\
\hline
\end{tabular}

Tablo 3: Hanımlar için kapıağaya teslim olunan esbâb beyanıdır. ${ }^{18}$

\begin{tabular}{|c|c|}
\hline Sipariş & Adet \\
\hline Kese akçe & 3 \\
\hline Sikke-i hasene & 6.000 \\
\hline Altın (..) & 1.500 \\
\hline Gümüş dirhem & 26.855 \\
\hline Serâser tak & 153 \\
\hline Altınlı çatma kadife tak & 117 \\
\hline $\begin{array}{c}\text { Altınlı frengi kadife ma 'a pare } \\
(\ldots) \text { sade pek hoş frengi kadife tak } 14\end{array}$ & 13 \\
\hline (...) Sade pek hoş frengi kadife tak & \\
\hline
\end{tabular}

17 Zirâ’: Arşııı da denirdi. Dirsekten orta parmak ucuna kadar olan uzunluk ölçüsüdür. Bkz. Ferit Devellioğlu, Osmanlıca-Türkçe Ansiklopedik Lügat, Ankara, Aydın Kitabevi, 1995, s. 1188.

18 BOA, TSMA.d,7859.0001.00, 29 Z 969/ 30 Ağustos 1562., BOA, TSMA.d,7859.0002.00, 29 Z 969/ 30 Ağustos 1562. 


\begin{tabular}{|c|c|}
\hline Kadife $(\ldots)$ tak & 33 \\
\hline Kadife $(\ldots)$ pare & 76 \\
\hline Frengi kemhâ tak & 116 \\
\hline Frengi atlas tak & 37 \\
\hline Şam atlas tak & 10 \\
\hline Kemhâ Bursa ve Amasya tak & 126 \\
\hline Altınlı ve sade kadife münakkaş yastık & 33 \\
\hline Altınlı kumaş $(\ldots)$ & 10 \\
\hline Peşkir yemeni & 10 \\
\hline Seccade & 20 \\
\hline Mütenevvi' minder & 15 \\
\hline Mütenevvi' yastık & 30 \\
\hline Mütenevvi' yorgan & 33 \\
\hline Tülbent kıt'a & 397 \\
\hline Renkli tülbent kit'a & 36 \\
\hline Bakır sini & 10 \\
\hline Büyük ve küçük bakır tepsi & 36 \\
\hline$(\ldots \ldots)$ & 3 \\
\hline Miyane maşrapa & 6 \\
\hline Miyane üsküre & 6 \\
\hline Pirinç şam 'dan & 6 \\
\hline Safran şam 'dan & 8 \\
\hline Büyük abdest leğeni & 3 \\
\hline Abdest ibrik & 6 \\
\hline Al leğen ma'a ibrik & 3 \\
\hline Astar k1t'a & 200 \\
\hline Yanbolu kese & 20 \\
\hline Yengelere akçe & 90.000 \\
\hline$(\ldots \ldots)$. & 1.000 .000 \\
\hline Duhâvî frengi tak & 23 \\
\hline Büyük ve küçük (...) & 72 \\
\hline Yazlık ibrişim (...) & 18 \\
\hline
\end{tabular}




\begin{tabular}{|c|c|}
\hline$(\ldots)$ atlas zirâ & 1.000 \\
\hline (...) frengi kadife zirâ & 320 \\
\hline Serâser ${ }^{19}$ & 2 \\
\hline Altınlı (...) & 7 \\
\hline Frengi kemhâ & 5 \\
\hline Frengi atlas & 5 \\
\hline Serâser yaz kaftan & 3 \\
\hline Serâser hil' ât kaftan & 10 \\
\hline Serâser yaz kaftan & 3 \\
\hline Serâser hil' ât kaftan & 10 \\
\hline Serâser & 2 \\
\hline Altınlı (...) & 8 \\
\hline$(\ldots)$ & 5 \\
\hline Atlas & 5 \\
\hline Serâser yaz kaftan & 3 \\
\hline Serâser hil'ât kaftan & 10 \\
\hline Serâser & 2 \\
\hline Altınlı $(\ldots)$ & 8 \\
\hline$(\ldots)$ & 5 \\
\hline Atlas & 5 \\
\hline
\end{tabular}

Yukarıdaki tablolar incelendiğinde 16.yy da hanım sultanların, ileriki dönemlerde sarayda bulunan kadınlara göre elmas ve pırlanta yerine, daha çok inci ve lâl taşını tercih ettikleri görülmektedir. 19.yy Osmanlı'sında, Hazine-i hassa'ya 3.032.159 kuruşa mâl olan Adile Sultan'ın otuz sayfayı bulan çeyiz listesi buna örnek verilebilir. ${ }^{20}$

Çocukluğu Sultan Abdülmecid dönemi'nin sonuna kadar sarayda geçmiş olan Leyla Saz Hanımefendi; Cemile Sultan'ın çeyiz sergisinden detaylı bir şekilde bahseder ve mücevheratın çeşidi hakkında bilgi vermektedir. Onun aktardıkları iki dönem arasındaki farklılıkları yansıtmaktadır. ${ }^{21}$

19 Serâser ve devamındaki malzemeler sevk? Hanım'a gönderilen esbâb beyanıdır.

20 Olcay Kolçak, Adile Sultan, İstanbul, Kastaş Yayınevi, 2005, s. 72.

21 Leyla Saz, Haremde Yaşam, haz. Sedat Demir, İstanbul, DBY Yayınları, 2012, s.166. 
Şah Sultan'a ait bir diğer vesika ise babası II. Selim'e yazmış olduğu mektuptur. ${ }^{22}$ Kendi el yazısı olduğundan emin olamasak da, onun dilinden, elimize kalan tek belge olması bu mektubu mühim kılmaktadır. Şah Sultan'ın babasına dua ve tazimlerini içeren ve kendisini görmek istediğini belirten mektubun Latin harflerine aktarılmış şekli aşağıda yer almaktadır. Şah Sultan'ın mektuptaki ifadesinden babasını göremediği için sitem ettiği anlaşılmaktadır.

'Şerîfü'l-hisāl ve hasînü'l-hâl ve sâhibü's-sa âdet ve'l-iclâl olan sa 'âdetlü şâhımun ve mürüvvetlü pâdişâhımun rikâb-ı hümâyûnlarına envâ'-i ta'zîmât birle du'âlar (...) senâlar 'arz olundukdan sonra inbâ olunur ki, cihâna vücûd-l şerîfleri nizâm virsin ve 'âleme zull-i sa âdetleri intizâm virsin saâdetimün mübârek mizâc-l şerîfleri ve cism-i latîfleri nicedür deyü bu za îfenin dâima hâtırası olmasin eksüklük birle evkāt-ı sa îde du'a-i şerîfle meşgūl olmağı pîşe ve endîşe idinüp Cenâb-l Kädi'l-hâcâtdan me'mûldür ki karîn-i icâbetünde kulûbu dâima inâyetullâh ve mehâbet-i enbiyâ ve evliyâullah sultânımun vücûd-ı şerîfleri üzerlerine hâzır ve nâzır olup dâima sahîhü'l-mizâc oluna. Eger bu za îfeleri hâlinden isti 'lâm olunursa sultânımun mübârek yüzlerini görüp şâdân olmak ümîdinden gâyrı hâtıramız yokdur mercûdur ki ölmeden yine müşâhede (...) musâhebet müyesser ola, amîn Yâ Mûcibe'l-sâ'ilîn.

Cariyenüz (...) Şah Sultân”

Bir diğer vesikamız ise, Osmanlı Arşivi'nde bulunan Şah Sultan'ın payitaht dışında iken bulunduğu mahalde çıkan salgın hastalıktan ötürü başka bir yere nakledilmesinin bildirilmesi ile ilgilidir. Vesikanın Latin harflerine aktarılmış şekli aşağıdaki gibidir:

"Dergâh-ı muallâ'ya ve bârgâh-ı a'lâya ma'rûz-ı bende-i fakìr budur ki, dergâh-l felek-iştibâhdan hükm-i şerîf-i 'âlî̧̧ân ve edâ olup mazmûn-ı 'âisinde meliketǜl-melikât tâcüll-ûlâ vess-sa'âdât sultân hazretleri dâmet ismetuhâa oldukları köyde hastalı var deyu istimâ' olunmağın buyurdum ki, ol cânibde havâsı latîf yerde ten-dürüst köyler bulup göçüresin ve hastalı yerlerden oldukları köylere kimesne varmaya deyü emr olunmuş, imtisâlen li'l-emri'l- âlî veslhükmi>l-müte 'âlî ten-dürüst yerler görüp teftiş olundukda ahâlî-i memleket (...) hiç ol diyârın (...) hastalıksız (...) yer yokdur dediklerinden sonra haliyâ Haslar Kadısı Mevlânâ Pir Mehmed >e istifsâr olunup ol dahi ahâlî-i vilâyetin takrîrine muvâfik eger yaylaklar ve eger mahrûse-i İstanbul nevâhîsidir ten-dürüst yer yokdur deyü cevâb verip hükm-i şerif-i 'âlişan vârid olmadan evvel hazret- $i$ sultân-ı mu'azzama dâmet ismetuhâ hazretleri sa'adetli oldukları karyede has- 
talık vâkī olmağın sâ adetli ol karyeden kakup haslardan Mehmed Paşa Çiftliği demekle ma 'rûf karyeye gelüp bi'l-fi 'il sa âdetli karye-i mezbûrede olurlar. Göçürülmek hususu içün (...) vârid olan hükm-i şerîf 'arz olundukda şimdiki halde olduğumuz yerden ... hiç bir yer yoktur ki anda hastalık olmaya bu yerden gitmezüz. Şimdiki halde bu yer sihhat üzredir. Karye-i mezkûrede olduğumuzu 'arz eyle deyü bendelerine buyurduklart ve gayrı yere gitmeğe 'adem-i rızâları olduğu Dergâh-ı muallâ'ya 'arz olundu. Bâkī ferman Dergâh-ı muallânındır.

Bende el-fakîr Mahmud el-hakîr."23

Son olarak da Şah Sultan'ın Mühimme defterlerine geçen hac yolculuğu hakkındaki vesikanın latin harflerine aktarılmış şekli aşağıdadır.

"Sâhib-i devlet eliyle mezbûr sultâna virildi. Fi 4 Ra

Anatolı beğlerbeğisine hüküm ki: Seyyidetü'l muhadderât tâcü'l-mestûrât safiyyü's-sıfat meleketü'l-melekât iklîletü'l-muhassanât sâhibetü'l-hayrât ve'l-hakkât zâtü'l-alâ ve's-sa âdatu'l-mahfûf bi sunûfì avâtrfi'l-meliki'l-müste 'ân Şah Sultân dâmet ismetuhâ inâyet-i Rabbânî ve hidâyet-i Sübhânî mukarenetiyle tavâf-ı Beytu'llâhi'l-harâm ve ziyâret-i Ravza-i mutahhare-i hazret-i seyyidü'lenâm 'aleyhi's-salâti's-selâm niyeti ile ol diyâr-ı celîlü'l-i 'tibâr savbına teveccüh ve azîmet itmişdür ve ri 'âyet hımâyet lâzım olmağın buyurdum ki;

Müşârun-ileyhâ beğlerbeğiliğine dâhil oldukda ta zîm ve ikrâm ve tevkîr ve ihtiramında bi'z-zât mukayyed olup dakîka fevt itmeyüp savb'ul-mürûr ve mahûf olan yirlerden 'ahsen vechile mürûr u ubûr itdürmekden ve akçesiyle zehâyiri ve sâyir mühimmâtı tedârükinde ihtimâm idüp ve kifâyet mikdârı âdem koşup vilâyet-i Karaman muhâfazasında olan Niğde beği Mehmed dâme uluvvuhûya emîn ü sâlim ulaşdurmakda dikkat ü ihtimâm idüp dakîka fevt eylemeyesin."

Bu hükmün birer kopyası Adana ve Halep Beylerine de verilmiştir. Aşağıda ise Şam Beylerbeyi'ne gönderilen hüküm yer almaktadır.

Şam Beğlerbeğisine hüküm ki;

Seyyidetü'l muhadderât ilâ âhâr dâmet ismetuhâ hidâyeti'l-mu 'ûn ve inâyet-i nâ-mütenâhî mukareteyn ile tavâf-ı Beytullâhi'l-hârâm ve ziyaret-i Ravza-i mutahhara-i seyyidü'l-enâm 'aleyhi's-salâti ve's-selâm niyetiyle ol diyâr-l celîlü'litibâr savbına teveccüh ve azîmet itmişdür buyurdum ki;

Müşârun-ileyhâ beğlerbeğiliğine dâhil oldukda ta zîm ve ikrâm ve tevkîr ve ihtiramında bi'z-zât mukayyed olup dakîka fevt eylemeyüp râh-ıHicâz'a müte 'allık levâzım ve mühimmâtın her ne ise akçesiyle murâdı üzre tedârük ve tekmîl 
idüp mühimmâtına kusûr u noksân eylemeyesin ve Kudus-i şerif ziyâretine vardukda kifâyet mikdâr müsellem ve yarar âdemler koşup ziyâret itdirüp ve Haremeyn-i şerîfeyn'emüteveccih oldukda müşârun-ileyhâ evvelki katarda yürümek münâsibdür mîr-i hüccâca ana göre tenbîh ü te 'kîd eyleyesin ki evvel ki katarda mürûr itdürüp ta zîm ve ikrâmında ve levâzımı tedârükinde dakîka [fevt] eylemeyüp menâzil ü merâsilde lâzım olan mühimmât ü levâzımın bi'z-zât görüp bir husûsda muzâyaka çekdirmeye.

Şam mîr-i hüccâcina hüküm ki:

Seyyidetü'l-muhadderât ilâ âhir dâmet ismetuhâ ınâyet-i sübhân̂̂ ve hidâyet-i samedânî mukâreneti ile tavâf-ı Beytullâhi'l-haram ve ziyâret-i Ravza-i hazret-i seyyidü'l-enâm aleyhi's-salâti ve's-selâmın niyyeti ile ol mâkâmât-ı şerîfe savbına müteveccih olmışdur ri âyet ü hımâyet vâcîb ü lâzım olmağın buyurdum ki;

İnşâallâhü te 'âlâ mahmiyye-i Şam'dan râh-ı Hicâz'a teveccüh olındukda müşârun-ileyhâyı baş katardan mürûr itdürüp ve cemîlevâzım ve mühimmâtı tedârükinde mukayyed olup menâzil ü merâsilde görüp gözedüp ve mühimmât u levâzımı husûsı dâimâ mürâca'at idüp her ne lâzım ise akçesiyle tedârük ve ihzârında dakîka fevt itmeyüp bi 'l-cümle şükr ü şikâyet tamâm müsemmir ve müessir bilüp hıdmetinde bi'z-zât mukayyed olup varılup gelinince bir husûsda [muzâyaka] çekdürmeyüp hıdmet ve levâzımında ihmâl ü tekâsülden ziyâde hazer eyleyesin. ${ }^{24}$

\section{Zal Mahmud Paşa'nın Hayatı}

Zal Mahmud Paşa'nın hayatının ilk yılları hakkında kaynaklarda bilgi bulunmamaktadır. Alderson, 1521 yılında doğduğu bilgisini vermiştir. ${ }^{25}$ Gelibolulu Âlî, onun Bosnal1 ${ }^{26}$ olduğunu söyler. Gerlach ise Mahmud Paşa'nın Laibach ${ }^{27}$ kentinden olduğu bilgisini vererek, Alman asıllı olduğunu ifade eder. ${ }^{28}$ Babinger de kaynak belirtmeden onun Alman asıllı olduğunu bildirmiştir. ${ }^{29}$ Mahmud Paşa,

24 Muharrem Bostanc1, “19 Numaralı Mühimme Defteri”, (Yayımlanmamış Yüksek Lisans Tezi), İstanbul Üniversitesi Sosyal Bilimler Enstitüsü, İstanbul 2002, s. 303-305.

25 A. Dolphin Alderson, Bütün Yönleriyle Osmanlı Hanedanı, çev. Şefaettin Severcan, İstanbul, Yenişafak, 1999, s. 249.

26 Gelibolulu Mustafa Âli, Künhü'l-ahbâr, İstanbul Üniversitesi Nadir Eserler Ktp., nr. 5959, vr. $437 a-437 b$.

27 Habsburglar zamanında Avusturya topraklarında yer alan bugün Slovenya'nın başkenti konumunda olan Ljubljana şehri kastedilmektedir.

28 Stephan Gerlach, Türkiye Günlüğ̈̈, I, çev. Türkis Noyan, ed. Kemal Beydilli, İstanbul, Kitap Yayınevi, 2007, s.486.

29 Franz Babinger, Osmanlı Tarih Yazarları ve Eserleri, çev. Coşkun Üçok, Ankara, Kültür ve Turizm Bakanlığı Yayınları, 1982, s. 344. 
sarayda kapıcıbaş1 $11 \mathrm{k}^{30}$ görevinde bulunmuştur. Bu görevi sırasında, 1553 yılında yaşadığı olay ile ikbal merdivenlerini hızlıca tırmanmıştır. Kanuni Sultan Süleyman'in Mahidevran Sultan'dan olan oğlu Şehzade Mustafa'y1 Hürrem Sultan ve Rüstem Paşa'nın kışkırtmaları sonucunda boğdurmaya karar vermesine sevk etmiş, bütün bunların üzerine İran seferine çıkılmış, Şehzade Mustafa Konya'ya davet edilmiş, padişah da 5 Ekim 1553 'de Konya Ereğlisi yakınlarında otağını kurdurmuştur. ${ }^{31} 6$ Ekim günü Şehzade Mustafa babasını görmek için otağ-1 hümayuna girmiş ve çadırın içindeki dilsiz cellatlar tarafından yay ipiyle boğulmaya çalışılmış ancak güçlü ve kuvvetli şehzade cellatların ellerinden kurtulmayı başarmışsa da o sırada henüz kapıcıbaşı olan Mahmud'un şehzadeyi ayağından yakalaması sonucunda yere serilmiş, Mahmud Ağa'nın kemendi ve yahut da cellatlar eliyle hayatına son verilmiştir. ${ }^{32}$

Pehlivanlığ 1 ile müsemma Mahmud Ağa'ya Kanuni tarafından "Zal"33 lakab1 verilmiştir. ${ }^{34}$ Kanuni'nin gözüne giren Mahmud Ağa, kapıcıbaşılıktan sonra Halep ve Budin Beylerbeyliklerine ardından da Anadolu Beylerbeyliğine getirilerek rütbesi yükseltilmiştir. ${ }^{35}$ Zal Mahmud Paşa'nın Budin Beylerbeyliğine ne zaman getirildiğini belirleyemesek de 1563 y1lında 800.000 akçe gelirle o mansıbda görev aldığ tespit edilmiştir. ${ }^{36}$ Ardından mühimme kayıtları incelendiğinde "sâbıkā Budun Beğlerbeğisi olup hâliyâ Anatolı Beğlerbeğisi olan Mahmud",37 ibaresinden 1565 yılının başında Anadolu Beylerbeyliği makamına getirildiği anlaşılmaktadır. 1565 senesi ilkbaharında Avusturya üzerine sefere çıkılacağı bildirilerek, Zal Mahmud Paşa'ya emri altındaki sancakbeyleri, alaybeyleri, zaîm ve sipahilere tam techizatlı ve eksiksiz olarak sefere hazırlanmaları hususu tembih edilmiştir. ${ }^{38}$ Dört kaleden oluşan Sigetvar muhasarasının ilk günü Zal Mahmud Paşa, Ferhat Paşa ile birlikte Anadolu askerleriyle kaleyi bir yönden top ateşine

30 Gelibolulu Mustafa Âli, a.g.e, vr. 437a.

31 Şerafettin Turan, Kanuni Süleyman Dönemi Taht Kavgaları, İstanbul, Bilgi Yayınevi, 1997, s. 37.

32 a.g.e, s. 39.

33 Zal lakabı Zal oğlu Rüstem diye anılan İranlı pehlivandan gelmektedir.

34 Nazım Tektaş, Muhteşem Süleyman ’ın Gözyaşları, Şehzade Mustafa ve Bayezid, İstanbul, Çatı Kitaplar1, 2012, s. 90.

35 Gelibolulu Mustafa Âli, a.g.e, vr. 437a.

36 Geza David, "Budin", DİA, VI, İstanbul, 1992, s. 346.

376 Numaralı Mühimme Defteri (972/1564-1565), haz. Hacı Osman Yıldırım vd., I, Ankara, Osmanlı Arşivi Daire Başkanlığı Yayınları, 1995, s. 347.

385 Numaralı Mühimme Defteri (973/1565-1566), haz. Hac1 Osman Y1ldırım vd., I, Ankara, Osmanlı Arşivi Daire Başkanlığı Yayınları, 1994, s. 95. 
tutmuştur. ${ }^{39}$ Seferin sonuna gelindiğinde ise Zal Mahmud Paşa kereste yetiştirme işini üzerine almış, bu arada Bobofça Kalesi de zapt edilmiştir. ${ }^{40}$

Kanuni Sultan Süleyman'ın vefat etmesi ve Sigetvar'ın fethi üzerine Şehzade Sultan Selim Belgrad'a geldi. Tahtın yeni sahibi II. Selim'in ilk icraatlarından biri de Anadolu Beylerbeyi olan Zal Mahmud Paşa'ya vezaret ${ }^{41}$ rütbesi vermesi oldu ve kızı Şah Sultan'1 onunla evlendirdi. Zal Mahmud Paşa, II. Selim ve III. Murad dönemlerinde dördüncü vezir olarak görevine devam etti. ${ }^{42} \mathrm{Bu}$ dönemde, Sokollu Mehmed Paşa'nın ön planda olmasından dolayı kaynaklarda adı çok zikredilmemektedir. Bu da aktif, belirgin bir siyaset içerisinde bulunmadığını düşündürmektedir. Şah Sultan ile beraber At Meydanı'nda bir konakta oturduğu bilinmekle beraber, İbrahim Paşa Sarayı'nda ikamet ettikleri de söylenmektedir. ${ }^{43}$

Gerlach, onun cenaze töreninde bulunmuş hizmetkârlarının arkasından gözyaşı döktüklerini, devlet erkânı yanında halkın da cenazeye katıldığından bahsetmiştir. Ayrıca,

“...ölenin oğlu, sarığının üstüne siyah bir mendil örtmüss, atı üzerinde onlarl takip ediyordu. "44 şeklindeki ifadesinden Zal Mahmud Paşa'nın bir oğlu olduğu düşünülmekteyse de kaynaklarda bunu destekleyecek başka bir bilgi mevcut değildi. Fakat, türbede üçüncü bir sandukanın olması bu bilginin doğru olabileceğini akla getirmiştir. Osmanlı Arşivi'nde yer alan bir vesikada Zal Mahmud Paşa'nın Muhammed Paşa adında bir oğlu olduğu ve oğlunun 1596 senesinde Diyarbakır muhafazasına getirildiği görülmektedir. ${ }^{45}$ Ayrıca, Zal Mahmud Paşa'nın torunu Hasan Bey'in de adının geçtiği vesikanın varlığından, Gerlach'da yer alan bilginin doğru olduğu anlaşılmaktadır. ${ }^{46}$ Fakat, vakfiyede Şah Sultan'ın ailesinin zikredilip, Zal Mahmud Paşa'nın oğlunun adının geçmemesi ise onun Şah Sultan'dan değil de daha önce yapmış olabileceği bir evlilikten olduğunu düşündürmektedir.

39 Feridun Ahmed Bey, Nüzhet-i Esrarü'l-Ahyâr Der-Ahbâr-ı Sefer-i Sigetvar, haz. Ahmet Arslantürk, Günhan Börekçi, İstanbul, 2012, s. 111.

40 Selânikî Mustafa Efendi, Tarih-i Selâniki, I, haz. Mehmet İpşirli, İstanbul, Edebiyat Fakültesi Basımevi, 1989, s. 39.

41 Feridun Emecen, "Selim II”, DIA, XXXVI, İstanbul, 2009, s. 416.

42 Zal Mahmud Paşa III. Murad'ın protokol gereği padişaha biat etmek için cülûs töreninde yerini almıştır. İlgili minyatür ekler kısmında yer almaktadır. Ayrıntılı bilgi için bkz. Zeynep Tarım Ertuğ, XVI. Yüzyıl Osmanlı Devleti’nde Cülûs ve Cenaze Törenleri, Ankara, Kültür Bakanlığ1 Yayınlar1, 1999, s. 75-76.

43 Semavi Eyice, “İbrahim Paşa Külliyesi”, DİA, XXI, İstanbul, 2000, s. 345.

44 Gerlach, a.g.e, II, s. 654.

45 BOA, A.DVNS.MHM.d., 74/214, 18 S 1005/ 11 Ekim 1596.

46 BOA, A.MKT.NZD., 87/78, 22 Za 1269/ 11 Kasim 1846. 
Zal Mahmud Paşa, Şah Sultan ile birlikte Eyüp'te cami ve medrese yapımı için harekete geçmiş ancak külliyenin tamamının bittiğini göremeden 22 Ekim 1577 tarihinde vefat etmiştir. Eyüp'te yapımı devam eden caminin bahçesine defnedilmiştir. Zal Mahmud Paşa'nın Eyüp'te yaptırmış olduğu külliyenin dışında Pirlepe'de bir çeşme, hamama su temini ve yine Ankara'da bir çeşme ile mescit inşa ettirdiği bilinmektedir. ${ }^{47}$ Gelibolulu, Zal Mahmud Paşa'nın adaletiyle meşhur, cömert, mülayim bir adam olduğundan bahsetmektedir. ${ }^{48}$

\section{Vakfiyesi Işı̆̆ında Şah Sultan ve Zal Mahmud Paşa Külliyesi}

Hicri 1002 (1594) yılında Osmanlıca kaleme alınan vakfiye, uzun bir giriş bölümüne sahiptir. Kurucuların isimleri ile vakıf eserlerinin tesis edildiği mekanı bildirerek başlayan vakfiyenin davet kısmı; "Duasında beni zikretmeyenin, duasının kabul edilmemesi haktır.", "Benim sahabilerim yıldızlar gibidir, hangisine uyarsanız hidayete erersiniz", "Allah adaleti ve iyiliği emreder" şeklindeki hadislere ve Hz. Peygamber ile onun ashabına duyulan sevgiyi gösteren ifadelere, ardından da Asr-1 Saadet'ten Şah Sultan ile Zal Mahmud Paşa'nın yaşadığı zamana kadar İslam alemine hizmet etmiş olan alimler için dualara yer verilmiştir. ${ }^{49}$

İki ayrı gezegene ve bir ip üzerine uygun şekilde dizilmiş, padişahlara yaraşan inciye benzetilen Zal Mahmud Paşa ve Şah Sultan'ın izdivaç ederek bir burçta birleşmeleri, tıpk1 ay ve güneş gibi yüce bir yolda bir araya geldiklerinden bahsedilmiştir. Bulunmaz iki cevher şeklinde nitelenen sultan ve paşanın, fakirleri kollayıp gözetmelerine dikkat çekilerek güzel vasıfları dile getirilmiştir. Allah'ın afv ve gufranına eriştikten sonra bile bağışlarının ebedi olduğu, fakir müslümanlar ve gayrimüslimlerin onların iyiliklerinden yararlandıkları anlatılarak, vakıf sahiplerinin güzel vasıfları övülmüştür. Ardından dünya hayatının geçiciliği, burada elde edilen mal ve mülkün ahirette fayda sağlamayacağı, ancak onların vakıf kurmak gibi faydalı işlerde kullanılması ile müminlerin dua ve övgüsünü kazanıp, Allahın affını kazanacağı konusu üzerinde durulmuştur. Hayır yapmanın önemi; "Cömert bir kimse hayatını cömertlikle geçirir ve tüketirse ona ikinci bir ömür garanti edilir." hadisi ve "Allah adaleti ve iyiliği emreder" ayeti ile pekiştirilmiştir. ${ }^{50}$

47 Musa Günay, “55 Numaralı Mühimme Defteri (992-993/ 1584-1585)”, (Yayımlanmamış Yüksek Lisans Tezi), 19 Mayıs Üniversitesi Sosyal Bilimler Enstitüsü, Samsun, 1996, s. 223.

48 Gelibolulu Mustafa Âli, a.g.e, vr. 437b.

49 Betül Kahraman, "Vakfiyesi Işı̆̆ında Şah Sultan ve Zal Mahmud Paşa Külliyesi: Cami, Medrese, Türbe ve Çeşmesi”, (Yayımlanmamış Yüksek Lisans Tezi), Fatih Sultan Mehmet Vakıf Üniversitesi Lisansüstü Eğitimi Enstitüsü, İstanbul, 2019, s. 27.

a.g.t, s.28. 
Vakfiyenin devamında, Zal Mahmud Paşa'nın 10 Muharrem 985'de (30 Mart 1577) Şah Sultan'ın ise paşadan on üç gün sonra vefat ettiği hatırlatılarak, kalan mallarının üçte biri ile bir cami, medrese ve kararlaştırdıkları hayrat ve vakıfları kendileri hayattalarmış gibi tamamlanıp, bitirilmesini hatta Şah Sultan'ın mallarının söz edilen üçte birinden başka diğer üçte ikisini de vakfetmesini kardeşi III. Murad'dan rica ettiği, o tarihte hayatta olan Valide Nurbanu Sultan'in da bu iş için vasî yapıldığı, hayratlarının mütevelliliğine ise Zal Mahmud Paşa'nın divan katibi Hüseyin Ağa'nın getirilmesi, mal varlığı ile vakfın durumunun takibi için hangi asır olursa olsun vezir-i âzamın nazır olması şeklindeki vasiyetinden söz edilmiştir. Verilen bilgilerden Şah Sultan ile Zal Mahmud Paşa'nın aslında aynı külliye içerisinde fakat kendilerine ait farklı vakıflara sahip olduğu anlaşılmaktadır. Şah Sultan da eşi Mahmud Paşa gibi Hüseyin Ağa'yı kendi vakfına mütevelli olarak seçmiştir. Böylece Hüseyin Ağa hem Şah Sultan hem de Mahmud Paşa'nın vakfının mütevelliliğini yürütmüştür. Bununla beraber, Şah Sultan'ın kız kardeşleri olan Gevherhan, İsmihan ve Fatma Sultanlar ise Şah Sultan'ın mirasından kendilerine düşen hisseden feragat edip, ağabeyleri III. Murad'ın da izniyle malları vakf ederek, Şah Sultan'ın son arzusunu yerine getirmişlerdir. ${ }^{51}$

Vakfiyenin devamında ise Mahmud Paşa ve Şah Sultan'ın mal varlıkları ve bunlarla yapılan harcamalar üzerinde durulmuştur. Buna göre, Zal Mahmud Paşa'nın malının üçte biri toplam 2.857.665 akçe, Şah Sultan'ın ki ise 3.018.008 akçedir. Şah Sultan'a ait olan bildirdiğimiz miktarın içerisinde tüm malına ek olarak, mehri ile paşadan kendisine kalan sekizde bir oranındaki miras da bulunmaktadır. Şah Sultan ve Zal Mahmud Paşa'nın vasiyetleri gereğince vefatlarının yedinci ve kırkıncı günü müslümanların fakirlerine yemek verilerek, kılamadıkları namazların ve tutmadıkları oruçların, hac ve yemin gibi telafisi mümkün olan diğer dini vecibelerin her birine kefaret olması için 1skat verilmiştir. Kararlaştırılan meblağ her birinin vasiyetleri üzerine sarf olunduktan sonra kalan miktar muhasebe defterine kaydolunmuştur. Vakfiye'nin geri kalanında iki ayrı vakfa sahip olan eşlerin, Zal Mahmud Paşa'nın vakfı mali açıdan zayıf düştüğünden birleştirildiği, vakfın akarları, idari hususlar ve şartlardan bahsedilmiştir. Bunlardan detaylı bir şekilde aşağıda bahsedilecektir. Ayrıca vakfın muhasebesinin her sene vezir-i azam huzurunda yapılması ve arta kalan paranın mütevelliler tarafından deftere geçirilip, saklanmasına karar verildiği, ilerleyen vakitlerde vakfın darlık yaşamasına karşın 5 yük akçenin her zaman istirbah edilmesi, artan paralardan Şah Sultan'ın vasiyeti gereğince medreselere lazım olan kitapların vakf edilip bir hafız-1 kütüb tayin edilmesi, gelir getirecek uygun akarlar satın alınması, görevlilerin ücretleri ile hay- 
ratların arttırılması, ilimde hevesli olup, fakir olan öğrencilere 1 akçe, danişmentlerin fakirlerine ise 10'ar akçeye varıncaya dek ek ücret verilerek, odalarda sâkin olmaları şeklindeki konular üzerinde durulmuştur. Bunlara ilaveten vakfin mali durumana göre iki üç senede bir yahut her sene Şah Sultan ve Zal Mahmud Paşa'nın ruhları için bir sene birinin, diğer sene ise ötekinin niyetine hacca gidilmesi, on beş kişinin her gün tesbih edip cüz okuması şart edilmiştir. ${ }^{52}$ Yapılan hesaplamalar sonucunda, harcamalardan arta kalan 260.308 akçeden 86.000 akçenin Pirlepe'deki çeşmenin suyolu için harcanacağı, kalan 174.308 akçenin Hüseyin Ağa'nın sefere gitmesinden ötürü onun yerine getirilen, Mütevelli Mustafa Kethüda'ya teslim edildiği bildirilmiştir. Son olarak vakfiye, hukuki dayanaklar ve şühûdü'l-hâl kısmı ile bitirilmiştir. Çoğu vakfiyede olduğu gibi vakıf şartlarının değiştirilemeyeceğine ve vakfa son verilemeyeceğine dair "kim ki, onu işittikten sonra değiştirirse onun günahı değiştiren üzerinedir, muhakkak ki Allah işiten ve bilendir" ayeti zikrolunup, vakıf bedduası edilmiştir. Ayrıca vakfiyenin sonuna eklenen bir şerhte, her sene vakıf mütevellisinin, Eyüp Sultan Cami ve Külliyesi Vakfı'na 320 akçe ödeme yapması istenmekte ve bu uygulamanın kesintiye uğramadan devam ettirilmesi, kimsenin de buna mani olmaması istenmektedir. ${ }^{53}$

II. Selim'in kızı Şah Sultan ile II. Selim-III. Murad dönemlerinde vezirlik yapmış eşi Zal Mahmud Paşa'nın İstanbul Eyüp’te vakıf olarak inşa ettirdikleri külliye, zeminin eğimli olması nedeniyle iki kademede inşa edilmiştir. Zal Paşa Caddesi yönündeki ilk kademeye cami, şadırvan avlusu ve avluya birleşen bir medrese bulunmaktadır. İkinci alt kotta, Defterdar Caddesi yönünde yer alan alanda, ikinci medrese ile türbe binası ve bu alanı sınırlayan avlu duvarının dış yüzüne bir çeşme yerleştirilmiştir.

Zal Mahmud Paşa'nın Ankara ve Filibe'de de vakıf eserleri bulunmaktadır. $\mathrm{Bu}$ vakıflar Eyüp'teki vakfın idaresiyle birleştirilmiştir. Daha öncede belirttiğimiz gibi en başta vakıflar paşa ve sultan tarafından ayrı ayrı kurulmuşlardır. Hatta Şah Sultan'ın vakfı için babası II. Selim'in vakfından borç aldığı bilinmektedir. ${ }^{54}$ Ayrıca II. Selim kızı Şah Sultan'ın yaptırmak istediği vakıf için 1567 senesinde Filibe'de Persadin ve Pavlikan köylerinin Küpsi nahiyelerini, Dercek, Perestice, Şetce, Savver, Fevniye, Vaslakuh, Peruskuva, Curel, Meldava, Vaştova, Nevsel Çavuş ve Nevsel Cedid köylerini temlik ederek, vakfetmesine müsaade etmiştir. Osmanlı Arşivi'nde yer alan bir arzuhalde mütevelli olan Kara Kethüda'nın

52 a.g.t, s. 29.

53 a.g.t, s.30.

54 İstanbul Kadı Sicilleri Üsküdar Mahkemesi: H.1000, M. 1592, cilt 10, İstanbul, İSAM Yayınlar1, 2008, s.138. 
Zal Paşa'nın vakfının gelirlerinden 20 yük akçe, Şah Sultan'ın vefatından sonra yılda 1 yük akçe olmak üzere on iki yıldır bunları zimmetine geçirdiği, paşanın 45 yük akçesinden bir akçe gelir kalmadığ 1 ve yılda 74.000 akçe Şah Sultan'ın vakfının kârından karşılandığı dile getirilerek, 105 yük akçeden 82.040 akçesinin muhasebesinin yapılmadığı ileri sürülmektedir. Arzuhalde ekl edilen yani zimmete geçirilen 20 yük akçenin tahsil edilip vakfın muhasebesinin yapılması istenmiştir. ${ }^{55} 1585$ tarihinde Zal Mahmud Paşa'nın vakfının malî olarak zor duruma düşmesi üzerine mütevelli ve dönemin vezir-i azamının önerisi, padişahın uygun görmesiyle paşanın vakfının zararının Şah Sultan'ın vakfının kârından karşılanması ve 1002 yılında vakıfların birleştirilmesi, vakfın muhasebesinin her sene vezir-i azam huzurunda yapılıp arta kalan paranın mütevelliler tarafindan deftere geçirilip, saklanmasına karar verilmesi bu bilgiyi doğrular niteliktedir. ${ }^{56}$

Zal Mahmud Paşa ve Şah Sultan hayatta iken inşasını planladıkları külliyenin ilk biten parçası 987 (1579) yılında öğretime açılan ve Şah Sultan'a nisbet edilen medrese olmuştur. Cami'nin temeli ise vefatlarından hemen sonra 985 (1577) yılında atılmıştır. Hafız Hüseyin Ayvansarayî Mecmua-i Tevârih adlı eserindeki Farsça bir tarih kıt'asında, caminin inşa tarihini 985 (1577) olarak vermiştir. ${ }^{57} \mathrm{Ca}-$ minin mimarının Sinan olduğu, fakat inşa safhalarını kalfasının takip ettiği düşünülmektedir. Mühimme defterlerinde yer alan 990 (1582) tarihli bir hükümde inşaatın kontrolünün Dergâh-1 âlî kapıcıbaşılarından olan Mimar Hüseyin Çavuş'a verildiği tespit edilmiştir. ${ }^{58}$ Zal Mahmud Paşa Camii'ni mükellef ve mükemmel olarak tanımlayan Evliya Çelebi, camiden

"bir irem bağı içinde iki tarafı ana yol olan aydınlık bir camidir ki, Osmanlı ülkesindeki vezir camilerinin içinde böyle aydınlık bir cami yapılmamıştır. 366 billûr cam ile süslenmiş bir camidir... Altı tamamen talebe hücreleridir. Güney tarafindaki avlusuna ... basamak merdiven ile çıkılır, zira bu camiin bir tarafi yüksek yarlı zemindir. Ĕger bu camiin tarzını, şeklini, yapısını olduğu gibi yazsak ciltli bir kitap olur. Bu camide olan mimarî özellik bir camide yoktur. Ölçülü kubbesinin dişında olan güzel tasarlanmış marifetler haddinden fazladır. Zamanımız mimarlarının öyle bir şirin işi yapmaya güçleri yetmez. Minberi, mihrabı ve müezzin mahfilindeki ince iş̧̧ilikler, meğer Sinop Kalesi'neki minberde ola. Avlusunun ü̧̈ tarafi medrese odaları ile süslenmiştir. Dört tarafindaki güllük gülistanlı içindeki bülbüllerin nağmeleri insana hayat verir. Minaresi

55 TSMA.e, 0530 , ts.

56 a.g.t, s.31.

57 Hâfız Hüseyin Ayvansarâyî, Mecmuâ-i Tevârih, haz. Fahri Ç. Derin, Vahid Çabuk, İstanbul, Edebiyat Fakültesi Basimevi, 1985, s. 110.

58 Mübahat S. Kütükoğlu, XX. Asra Erişen İstanbul Medreseleri, Ankara, Türk Tarih Kurumu Basımevi, 2000, s.304. 
gayet sanatlı ve yüksektir. Koca Mimar Sinan bu cami yapılışında bütün ustalı̆̆ını göstermiştir. "59 şeklinde bahseder ve mimar olarak da Sinan'1 gösterir. Caminin plan ve tasarımında ilgi çekici ayrıntılar bulunmaktadır. Cami’nin kubbesinin üç tarafı mahfiller ile çevrili, dikdörtgen biçiminde bir kütleye sahip, son cemaat yeri beş gözlü, tek minareli bir fevkanî yapıdır. ${ }^{60}$ Kareye yakın dikdörtgen planlı olan caminin kubbesi mihrap tarafında duvara gizlenmiş payandalarla, diğer tarafta ise yuvarlak fil ayaklara basan askı kemerlerle taşınmaktadır. Pandantifli kubbenin geniş kasnağı pencerelerle donanmıştır. Mihrap duvarına yaslanan merkezî kubbeyi üç taraftan kuşatan galerilerle Orta çă̆ Mimarlığg’nın mihrap önü kubbeli tasarımından ilham alındığı anlaşılmaktadır. Ayrıca, farklı olarak kubbe eteğine kadar yükseltilen galeriler, caminin dış görünümünü erken dönem Osmanlı binalarına yaklaştırmıştır. ${ }^{61}$ Vakfiye' de hatip, imam, vaiz, kayyım, sirâcî, muvakkit, müezzin, ferraş, buhûrî, noktacı, eczâhân, şeyh, imâm, ser-mahfil, hafızlar, ehl-i kuran, hafiz-1 mahzen, muvaşşahhân, muarrif, kanavâti, sandûkî, na athân ve mevlidhânın tayin edileceği kararlaştırılmıştır.

Cami görevlileri arasında dünyaya rağbet etmeyen, ilim ve dine bağlılığı ile tanınan yumuşak tabiatlı, doğru düşünebilen, vasıf sahibi, tecvidi iyi bilen, Kuran'1 güzel ses ve nağme ile okuyan, salih, vakur, akıllı ve ilim sahibi bir hatip tayin edileceği bildirilmiştir. Cuma ve bayram günleri vaaz etme görevine sahip hatibin alacağı günlük ücret 15 akçe olarak belirlenmiştir.

Camiye imam olarak salih, takva sahibi, iffetli ve dindar, namaz1, vacib olan ibadetleri ve sünnetleri yerine getiren, edepli iki kişinin tayin edilmesi şart koşulmuştur. Bu iki imamın alacakları günlük ücret 10 akçedir. Cemaatle eda olunan beş vakit namazda müslümanlara imamet edecek bu kişilerin nöbetleşe hizmet etmeleri ve sabah namazlarından sonra Yasin, ikindi namazlarından sonra Nebe, akşam namazlarından sonra ise Mülk suresinin tilâvet edilmesi istenmiştir. Bunlardan elde edilen sevâbın Hazreti Peygamber ile ashabının, vakıf sahiplerinin ve diğer müslümanların ruhlarına bağışlanması istenmiştir. ${ }^{62}$

Her Cuma namazından önce hadis ve tefsir bilen bir vaizin bulunması istenerek onun: "Rabbinin yoluna hikmetle ve güzel ögütle davet et."63, "Eğer kaba,

59 Evliya Çelebi, a.g.e, haz. Seyit Ali Kahraman, Yücel Dağlı, İstanbul, Yapı Kredi Yayınları, 2003, s. 356.

60 Aptullah Kuran, “Zâl Mahmud Paşa Külliyesi”, Boğaziçi Üniversitesi Dergisi, I, İstanbul, 1973, s.65.

61 İsmail Orman, “Zal Mahmud Paşa Külliyesi”, DİA, XLIV, İstanbul, 2013, s.110.

62 Kahraman, a.g.t., s. 35.

63 Kuran, Nahl, 16/125. 
katı kalpli olsaydın hiç şüphesiz etrafindan dağllır giderlerdi." ${ }_{64}$ ayetlerinden yola çıkarak irşat etmesini fakat "Allah'ın cezası şiddetlidir" 65 ayeti ile Allah'ın kahr ve celâl sıfatlarından dolayı cemaatin karamsarlığa kapılmamasını, Allah'ın ibadet eden kullarına gazap ile muamele etmeyeceğini "Rahmetim her şeyi kapsadı" "66, "Allahın rahmetinden ümit kesmeyin ${ }^{67}$ " fehvası ile Allah'1n affediciliğinin zikredilmesi tembihlenmiştir. Ayrıca ehl-i imanın, vakıf sahiplerinin ruhlarının, gelmiş geçmiş tüm Osmanlı sultanları ile hayır sahipleri zikredilerek, Hazreti Peygamber'e salavat getirilip, bunların Allah'tan affedilmeleri için el açılıp dua edilmesi istenmiştir. Yine her asır ve vakitte İslam padişahına gönülden, iyi hal üzerinde olması için hayır duada bulunulması, duanın başında ve sonunda salavat getirilmesi ve Fatiha ile bitirilmesi şart koşulmuştur. Bu vaiz günlük 15 akçe ile görev alacaktır.

Namaz vakitlerinin tayin edilmesi için ise günlük 4 akçe karşıllı̆ında bir müneccim ve muvakkit bulundurulması şart koşulmuştur.

Bunun dişında dört müezzinin görev alması istenmiş, bu müezzinlerin dindar, gül bahçesindeki bir bülbül gibi güzel sesli ve hoş nağmeli, kuralına uygun ezan okuyabilmesi şart koşulmuştur. Bu müezzinlerden üçünün günlük 5 akçe, müezzinlerin başı ve kıdemlisinin ise 6 akçe ücretle vazifede bulunacağ belirtilmiştir. Ve yine müezzinlerin nöbetleşe şekilde cuma namazından başka öğle, ikindi ve yatsı ezanlarını ardarda okuyup ikisinin ezan verip her gece teheccüd vermeyi ihmal etmemeleri, Cuma günleri ezan vaktinde dördünün de hizmetlerini terk etmeleri halinde diğer taraflarda bir ücret verilmemesi şart edilmiştir.

Ayrıca Kuran-1 kerimi ezberleyip hafız olan, kıraat ve tecvid ilminde hünerli sekiz hafızın bulunması, bunların döneminin beğenilen kimselerden seçilmesi istenmiştir. Cuma Namazı'ndan önce caminin mahfilinde toplanıp her birinin ardarda bir aşr-1 şerif okuması, içlerinden en iyi ve kıdemli, kıraat ilmi ile tecvitte hünerli olan birinin ser-mahfil olup devre başlayıp, diğer hafızların da aşr-1 şerif tilavetlerini bitirmesinden sonra "Muhammed içinizden hiçbir erkeğin babası değildir. Fakat o Allah'in elçisidir ve peygamberlerin sonuncusudur. Allah her şeyi bilmektedir." ${ }_{68}$ ayetini yüksek sesle, acele etmeden ve anlayarak okumaları şart koşulmuştur. Hafizların yedisinin günlük 2'şer akçeyle, ser-mahfil olanının ise günlük 5 akçeyle vazife yapacak olması hususu da eklenmiştir.

64 Kuran, Al-i İmran, 3/159.

65 Kuran, Enfal, 8/13.

66 Kuran, Araf, 7/156.

67 Kuran, Zumer, 39/53.

68 Kuran, Ahzab, 33/40. 
Ayrıca, hatiplerin içinden ser-mahfillik isteyenin iyi bir hatip olması şart koşulmuştur. ${ }^{69}$

Camide görev alanların içerisinde günlük 3 akçe karşıllı̆ıında görev yapan bir na athân da bulunmaktadır. Bu na athân'ın Farsça bilmesi, güzel ses ve ahenk ile, Molla Camisi'nde söylenen gazelin okunması istenmiştir. Bu gazele alternatif olarak ise bilinen, Farsça bir gazel okunması kararlaştırılmıştır.

Yine, güzel ahlaklı, dürüstlüğ̈ ile tanınan bir muarrif tayin edilmesi istenmiş, bu muarrifin günlük 3 akçe karşılığında Hz. Peygamber'in özelliklerini belirtmesi istenmiştir.

Caminin diğer görevlileri de kayyımlardı. Vakfiye'de iki kişinin kayyım olarak atanması, bunların seher vakti cami kapısını açıp, akşam vakti kapatarak camiyi koruma görevini yürütmeleri istenmiştir. Bununla birlikte silip süpürme işlerini ihmal etmeyerek, yerleri temiz ve hoş tutmaları işinden de sorumlu tutulmuşlardır. Her birinin günlük 4'er akçe alması kararlaştırılmıştır.

Kayyımların yanı sıra caminin temizlik işleri için ferraşlar da bulundurulacaktı. Bu ferraş caminin içini silip süpürerek, hizmeti karşılığında günlük 3 akçe alacaktı. İkinci ferraş ise günlük 1 akçe karşılığında tuvalet ve şadırvanın temizlik işlerinden sorumlu tutulmuştur. Eğer birinci ferraş bu hizmeti de görürse, ikinci ferraşlık görevi de hizmetine ilave edilecektir. Burada dikkat edilecek husus vakfiyede "ferraşe-i saniye" ibaresinin kullanılmasıdır. Yani ikinci ferraşlık görevi için bir kadının da hizmet verebileceği anlaşılmaktadır. Üçüncü ferraş ise medreselerin iç ve dış temizliği ile bunların tuvalet ve çeşmesinin etrafının temizlenmesi için görevlendirilmiştir. Bu hizmeti karşılığında günlük 3 akçe alacağı belirtilmiştir.

Kandilleri yakarak camiyi aydınlatma işleri için ise temiz ve dürüst iki sirâcî bulunup, günlük 2 akçe karş1lığında hizmet görmeleri istenmiştir.

Yine camiyi hoş kokularla donatacak güzel ahlaklı bir buhurî bulunması istenerek, bu buhurcunun her Cuma yer yer tütsü yakarak halkın burnunu güzel kokular ile doldurması istenmiştir. Buhurcunun bu görev karşılığında 6 akçe alacağı belirtilmiştir. Ayrıca türbede olduğu gibi camide de eczahânların tilavette bulunduğu sırada tütsü yakmayı ihmal etmemeleri tembihlenerek, hizmetlerinin sadece Cuma gününden ibaret olmadığı belirtilmiştir.

$\mathrm{Bu}$ görevlilerden sonra caminin altında bulunan beş odalı mahzenlerdeki malzemenin korunması için de bir hâfız-1 mahzen bulundurulması kararlaştırıl- 
mıştır. Bu kişi yağ, kandil, süpürge ve hasır gibi malzemelerin korunmasının yanı sıra mahzenlerin açılıp kapanması işinden de sorumlu tutulmuştur.

Camide otuz kişinin günlük 2 akçe karş1lı̆gında, Cuma gününden başka her gün vakıf sahipleri ve ehl-i imanın ruhu için hatim indirmeleri istenmiştir. Bunların içinden vakar sahibi birinin ser-mahfil olup, hatim tamamlandıktan sonra dua etmesi ve bunun karş11 l̆ğında da 1akçe alacağı belirtilmiştir.

Bunun yanında dürüst bir kimsenin günlük 1 akçe karşıllı̆ında sandûkî olarak tayin edilmesi ve bu kişinin cüzlerin bulunduğu sandığı getirip, cüzleri okuyuculara dağıtıp, sonra tekrar sıraya dizip sandığa koyması istenmiştir.

Vakfiye'ye göre günlük 1 akçe karşılığında bir de noktacı bulundurulacaktır. $\mathrm{Bu}$ noktacının cüzhanlar ve diğer görevlilerin hizmetlerini terk etmeleri halinde durumu tespit etmesi istenmiştir. Cüzhanlardan gelmeyen olup eksik kalan bir iki cüz olursa bunu kendisinin okuyup o gün yarı ücreti hak etmiş olacağı belirtilmiştir.

Cami ve medreselerin tamir işleri için ise bir meremmetçi olması ve tamire ihtiyacı olan yerleri mütevellinin bilgisi dahilinde tamir edip buraların takibini yapması istenmiştir. Vakfiye' de yapacağı tamir işleri için ise günde 3 akçe alacağ belirtilmiştir.

Ayrıca işini iyi yapan, güzel huylu bir kanavâtî'nin vakfin su yollarınının tamiri için hazır olması ve gerektiğinde su yollarını tamir edip, hizmetini ihmal etmemesi istenmiştir. Her zaman günlük 4 akçe ücret alması şart koşulmuştur. $\mathrm{O}$ sırada hizmet etmekte olan Üstâd Yusuf Kemâl'in ise işinin ehli olduğundan kendisine günlük 5 akçe verilmesi şart koşulmuştur. Su yolu deneticilerine ihtiyaç duyulduğunda ise günlük 1 akçe verilmesi istenmiştir. ${ }^{70}$

Vakfiye'de adı geçmeyen muhtemelen daha sonraki dönemlerde cami'de hizmet eden duagû ve ihlas suresini tilavet etmekle sorumlu ihlashanlar da tayin edilmiştir ${ }^{71}$. Bu duagûların kadınlardan da seçilebilmesi dikkate değerdir. ${ }^{72}$

Vakfyye'de Ramazan ayı ve başka diğer önemli günlerde görevlilere verilecek ikramiye de söz konusu edilmiştir. Buna göre, caminin imamlarına, hatibine, müezzinlerine, sirâcîlerine ve kayyımlarına baklavalık verilip, her imam ve hatibe ikişer 100 akçe, müezzinlere 100'er, iki kayyıma ve sirâcîlere ise 50'şer akçe verilmesi şart koşulmuş, toplamının 1.200 akçe olduğu belirtilmiştir. Ayrıca her sene Hz. Muhammed'in doğduğu ay olan Rebiülevvel ayında toplanıldığında sesi hoş bir mevlidhân tarafından Türkçe mevlit okunması istenmiştir. Mevlidhâ-

70 a.g.t, s.36-38.

71 BOA, C. EV, 28/1370, 23 Z 1118/ 28 Mart 1707.

72 BOA, AE.SMST.III., 130/10104, 29 Za 1183/25 Nisan 1770. 
nın alacağı ücret 1.000 akçe olarak belirlenirken, bunların muvaşşahhânlarına da 1.000 akçe verileceği belirtilmiştir. Bununla beraber vuku bulabilecek diğer masrafların ise vakıf bünyesinden ödenmesi istenmiştir. Vakıf tarafından cami ile medresenin ortasına bir de şadırvan inşa edilmiştir. ${ }^{73}$

Şah Sultan ve Zal Mahmud Paşa'nın külliyesinde iki ayrı medrese bulunmaktadır. İlk biten medrese Şah Sultan'a nisbet edilmiştir. Caminin son cemaat yeri karşısında bulunmaktadır. Kubbeli bir dershane, yine kubbeli sekiz hücre ile üstleri aynı tonozla örtülmüş değişik ölçü ve biçimde beş hücreden oluşmaktadır. ${ }^{74} \mathrm{Zal}$ Mahmud Paşa'ya nispet edilen medrese ise taş merdiven ile inilen türbenin de bulunduğu yaklaşık 4 metre aşağıda bulunan bahçede denize bakan kısımda yer alır. Burada bir umumi dershane, on talebe odası, çok say1da tuvalet ve çeşme bulunmaktadır. Müderrise günlük 50 akçe ücret verilmesi medresenin ellili medrese olduğunu göstermektedir. Şah Sultan ve Zal Mahmud Paşa'nın medreseleri yüksek dereceli medreselerden idi. Bununla birlikte daha sonraki y1llarda Fenârizade Şeyhi Mehmed Efendi'nin 60 akçe $^{75}$ ile müderrislik görevine getirilmesinden medresenin payesinin yükseltildiği anlaşılmaktadır. Vakfiyede medresede görev alacak iki müderris için akranları içinde parmakla gösterilen ve üstün, fazilet sahibi ve ilminde ilerlemiş kişiler olmaları istenmiştir. Günlük 8 akçe alan bu müderrislerin eğitimi aksatmamaları, sebepsiz yere dersi terk etmeyip, şeriat ve fikıh işlerinde geniş bilgisi olan, dinin emrettiği şeylere sımsıkı bağl kalan kişiler olması şart koşulmuştur. Ve dahil medresedeki müderris ile hariç medresenin müderrisinin bağlantısı olduğu kastedilerek, dahil medrese müderrisinin Sahn medreselerinin sekiz derecesinden birine ulaştığında Zal Mahmud Paşa'ya nisbet edilen hariç medresede görevli olan müderrisin bir paye ilerleyip, dahil müderrisi olması kuralından bahsedilmiştir.

Ve medreselerin müderrislerinin her birine akıllı, kabiliyetli, erdemli, bilgin ve faziletli muidler tayin edilmesi şart koşularak, ücretleri 8 akçe olarak belirlenmiştir. Her iki müderrise on ikişer danişmend verilmiştir. Yani medresede toplam 24 danişmend yer almıştır. Danişmendlere verilmek üzere günlük 2 akçe ayrılmıştır. Yine danişmendlere günlük 4'er akçe ile hücrelerde oturma hakkı verilmiş ve görev alacak bevvâb yani hademelere günlük 2'şer akçe ücret tahsis edilmiştir. Hademelere ücret dağıtımının müderrislerin elinden yapılması şart olunmuştur. ${ }^{76}$

73 a.g.t, s.39.

74 Kuran, a.g.e, s. 70.

75 Şeyhi Mehmed Efendi, Şakaik-i Nu'maniye ve Zeylleri, III, nşr. Abdülkadir Özcan, İstanbul, Çağrı Yayınları, 1989, s. 121.

76 Kahraman, a.g.t, s.41. 
Medreselerin kuruluşu sırasında bir kütüphane yer almamış, Saraybosna'daki Gazi Hüsrev Bey medresesi kütüphanesiyle, İstanbul Süleymaniye Camii'nin kütüphanesi gibi medresenin inşaatının sona ermesinden sonra artan para ile temin edilecek kitaplar ile kurulup hafız-1 kütüp tayin edileceği planlanmışsa ${ }^{77}$ da bunun gerçekleşmediği, bir kütüphanenin mevcut olmadığı arşiv belgelerinden anlaşılmaktadır. ${ }^{78}$

Şah Sultan ve Zal Mahmud Paşa'nın vasiyetleri üzerine karı koca yan yana defn olunmuşlardır. Eşlerin dışında türbenin içerisinde kime ait olduğu bilinmeyen bir sanduka daha mevcuttur. Onların vefatlarından sonra üzeri kubbe ile örtülü bir türbe inşa edilmiş ve bu türbe için 600.000 akçe sarfolunmuştur. ${ }^{79}$ Türbenin etrafinda sonraki dönemlerde yapılan definlerle küçük bir hazîre oluşmuştur. Bu hazîrede Şah Sultan ile Zal Mahmud Paşa'nın bazı hizmetkârları, medresede müderrislik yapmış kişiler ve bunların ailelerine ait kabirlerde bulunmaktadır. Hatta Suyolcuzade olarak meşhur hattat Eyüplü Mustafa Efendi'nin kabri bu hazirede bulunmaktadır. ${ }^{80}$

Türbedâr, bekçi, destârî, cüzhân, türbenin vazifelileri arasındadır. Günlük 5 akçe ile vazifelendirilen türbedârın, ağırbaşlı ve dindar olması şart koşulmuştur. Türbe için gece ve gündüzleri nöbetleşe çalışacak ve türbeyi bir an bile boş b1rakmayacak on iki bekçi tayin edilmiştir. Bu bekçilerin günlük ücretleri 1.5 akçe olarak belirlenmiştir. Yine Zal Mahmud Paşa'nın kabrinde günde 1.5 akçe ile vazifelendirilen, sandukanın imamesini sarıp düzeltecek bir destârî bulundurulması kararlaştırılmıştır. Ayrıca, Şah Sultan ve Zal Mahmud Paşa'nın ruhları için cüzhânların sabah namazından sonra türbede toplanıp, on beş cüz okumaları şart edilmiştir. Bu cüzhanların her birine günlük 2'şer akçe verilmesi kararlaştırılmıştır. Her gün camide olduğu gibi eczahanlar tilavet ederlerken, türbenin buhursuz kalmaması tembihlenmiştir. ${ }^{81}$

Şah Sultan ve Zal Mahmud Paşa'nın vefatlarından sonra yapımı tamamlanan külliyenin bir de çeşmesi bulunmaktadır. Bu çeşmenin kitabesi 998 (1589-1590) tarihlidir. Fakat bazı araştırmacılar, kitabenin eski bir fotoğrafına bakarak ortadaki "9" rakamının silikliğinden ötürü sayının aslında " 5 " olduğunu söyleyip, çeşmeyi 958 (1551) y1lına tarihlendirerek hataya düşmüşlerdir. ${ }^{82}$ Bununla birlikte, resto-

77 İsmail E. Erünsal, Türk Kütüphaneleri Tarihi: Kuruluştan Tanzimat'a kadar Osmanl Vakıf Kütüphaneleri, II, Ankara, Türk Tarih Kurumu Yayınları Atatürk Kültür Merkezi Yayını, 1988, s. 153.

78 bkz. BOA, MF.MKT., 241/64, H.29 C 1312/ 28 Aralık 1894.

79 Kahraman, a.g.t, s.41.

80 A. Ragıp Akyavaş, Âsitâne: Evvel Zaman İçinde İstanbul, Ankara, Türkiye Diyanet Vakfi Yayınlar1, 2008, s.278.

81 Kahraman, a.g.t, s.42.

82 Semavi Eyice, “Eyüp'de Zal Mahmud Paşa Camii”, Eyüp Sultan Sempozyumu V Tebliğler, İstanbul, Elma Matbaacilık, 2002, s.16. 
rasyonu yapılan çeşmenin kitabesi şu an net bir şekilde okunmaktadır. Kim tarafından yazıldığg bilinmeyen çeşmenin kitabesi aşağıdaki gibidir:

“Sâhibü'l-hayrât Şâh Sultân

Hazreti ma'â Zâl Mahmûd Paşa

Fî̀-sebîlillâh bu âbr etti sebîl

Selsebîl ede Hudâ ana cezâ

Teşne diller dediler târîhini

Çeşme-i mâ-i hayât-ı cân-fezâ",

\section{H.998 / M.1589-1590}

Vakfın idaresini elinde bulunduran görevlilerin başında mütevelli gelmektedir. Söz konusu vakfın mütevellisi vakfiyede kendinden sonra gelecek mütevellinin dürüst, vakfı görüp gözetecek bir kimse olmasını isteyerek, günlük 80 akçe karşılığ1 görev yapmasını şart koşmuştur.

İdari kadroda görev alacak diğer bir görevli ise kâtiptir. Bu kâtip siyakat ve hesaplamada mahir, muhasebe konusunda güvenilir olacaktı. Bu kâtibin vakfın iç ve dış gelir giderlerini usulüne uygun yazması istenmiş ve kendisine 15 akçe verilmesi uygun görülmüştür. Bunun yanında o sırada vakfın emektarı olan ve cami inşa edilene kadar zahmet çeken Kâtip Mahmud Çelebi'nin hizmeti boyunca günlük 20 akçe almasına karar verilmiştir.

Dürüst bir kimsenin ise câbî olup, gelirleri toplayarak her yıl İstanbul'a getirip, vakfin mütevellisine teslim edip, bu hizmeti karşılığında günlük 6 akçe ücret alacağı belirtilmiştir. ${ }^{83}$

Zal Mahmud Paşa ile Şah Sultan'ın yaptırmış olduğu vakıf eserleri için akar sağlamak gerekliydi. Bunun için Paşa ve Sultanın vefatlarından sonra Filibe'de vakıf için bir han inşasına başlandı. Bu han için 1.161.500 akçe sarfedilmiştir. Filibe'de bulunan bu han altmış üç hücre ve on altı dükkânı içine almaktadır. Hanın bulunduğu yer debbağhane, at pazarı ve umumi yol ile çevrilmiş durumdaydı. Vakfiye'de verilen bilgilerden anlaşıldığı üzere Filibe'deki hanın tamiri ve vakıf için değirmenler vakfedilmiştir. Bu değirmenler için 1.251 .563 akçe ödenmiştir. ${ }^{84}$ Filibe'deki han dışında Eyüp'te de caminin yakınında vakfa gelir sağlamak için günümüze ulaşamayan bir yapı inşa edilmiştir. Bu yapı aşağıdaki birimlerden oluşmaktadır. Dükkanların üstünde yer alan altı oda günlük 1 akçe karşılığında caminin imam ve müezzinlerine tahsis edilmiştir. ${ }^{85}$

83 Kahraman, a.g.t, s. 43.

84 a.g.t, s. 43.

85 a.g.t, s. 44. 
Zal Mahmud Paşa muhtemelen Anadolu beylerbeyliği sırasında Ankara'da da hayır eserleri yaptırmıştır. Bunlardan biri Haffaflarbaşı'nda bir çeşme, diğeri ise Figani Çelebi Mahallesi'nde yaptırmış olduğu mesciddir. Bunlara akar sağlaması için on üç dükkân yaptırmıştır. Bu dükkânların onarımı vakfın gelirlerinden karşılanacaktır. Çeşmenin Ab-keş ve bekçi olarak iki görevlisi bulunmaktadır. Figani Çelebi Mahallesi'nde yer alan Mescid'in ise imam ve müezzin olarak iki görevlisi bulunmaktadır. ${ }^{86}$

Ankara vakfının idarî personeli olarak bir câbî tayin edilmiştir. Bu vakıf İstanbul'daki vakfin mütevellisine bağlıydı. Câbî'nin dükkânlardan kirayı toplayıp, maaşlar ödendikten sonra kalan miktarı her sene İstanbul'daki mütevellilere göndermesi şart koşulmuştur. Ayrıca, tamir ihtiyacı olursa bunu bildirmesi ve masrafın Zal Mahmud Paşa'nın kurduğu vakıfların tamamından karşılanması istenmiştir. ${ }^{87} \mathrm{Zal}$ Mahmud Paşa'nın hayattayken Ankara'da yaptırdığı hayır eserlerinin dışında Pirlepe'de de bir çeşmesi bulunmaktadır. Ayrıca, Pirlepe hamamının suyunu da vakfetmiştir. Bunların tamir ve mühimmat masrafının vakfın tamamından karşılanması, Pirlepe'deki vakıf eserleri için bir câbî tayin edilmesi istenmiştir. $^{88}$

\section{Zal Mahmud Paşa ve Zal Paşa Sultanı Medreseleri Müderrisleri}

Şah Sultan ve Zal Mahmud Paşa'nın külliyesinde iki ayrı medrese bulunmaktadır. İlk biten medrese Şah Sultan'a nisbet edilmiştir. Atâi'de bulunan kayıtlara göre Mehmed Suudî Efendi Şah Sultan'a ait olan medreseye 987 (1579) y1lında ilk atanan müderristir. Mustafa b. Hüseyin b. Sinan ise 987 (1579) Zal Mahmud Paşa'ya ait olan ve inşası daha sonra biten ikinci medreseye atanan ilk müderris olmuştur. Vakfiye metninde müderrislerin 50 akçe alacağ 1 belirlenmiştir. ${ }^{89}$ Buradan medresenin 50'li medrese olduğu anlaşılmaktadır. Ancak, 1028 (1619) yılında Fenârizade Şeyhi Mehmed Efendi’nin müderrisliği sırasında 60 akçe $^{90}$ alması medresenin payesinin yükseltildiği ve Zal Mahmud Paşa medreselerinin Altmışlı medrese statüsünde olduğu anlaşılmaktadır. 1579'dan 1729'a kadar medreselerde çalışan müderrisler kronolojik olarak aşağıdaki tabloda gösterilmiştir:

86 a.g.t, s. 45.

87 a.g.t, s. 46.

88 a.g.t, s. 46.

89 a.g.t, 186.

90 Şeyhî Mehmed Efendi, Şakaik-i Nu'maniye ve Zeylleri, III, nşr. Abdülkadir Özcan, İstanbul, Çağrı Yayınları, 1989, s. 121. 
Tablo 3: Zal Mahmud Paşa ve Şah Sultan'ın medreselerinde görev alan müderrisler ve vazife seneleri

\begin{tabular}{|c|c|c|}
\hline Müderrisin İsmi & Vazife Seneleri & Vazife Ücreti \\
\hline Mehmed Suudî Efendi ${ }^{91}$ & 987 (1579) & \\
\hline Bahrî Hasan Çelebi ${ }^{92}$ & $987(1579)$ & \\
\hline $\begin{array}{l}\text { Mustafa b. Hüseyin b. Sinan } \\
\text { (Kethüda Mustafa Efendi) }^{93}\end{array}$ & $\begin{array}{c}987-991 \\
(1579-1583)\end{array}$ & $50^{94}$ \\
\hline Mehmed Efendi ${ }^{95}$ & $990(1582)$ & \\
\hline Abdülvehhab Efendi ${ }^{96}$ & $\begin{array}{c}991-995 \\
(1583-1586)\end{array}$ & \\
\hline Subaşızade Mehmed Efendi ${ }^{97}$ & $992(1584)$ & \\
\hline Hüseyin Hasîbîîn ${ }^{98}$ & $\begin{array}{c}992-996 \\
(1584-1587)\end{array}$ & \\
\hline Ahmed Efendi ${ }^{99}$ & $995(1586)$ & \\
\hline Ubudî Abdullah Efendi' ${ }^{100}$ & $996(1587)$ & \\
\hline Mehmed Efendi ${ }^{101}$ & $997(1588)$ & \\
\hline Ebü'l-Meyamin Mustafa b. Ali ${ }^{102}$ & 998 (1589) & \\
\hline
\end{tabular}

91 Mehmed Suudi tamamlanan ve Şah Sultan'a ait olan medreseye atanan ilk müderristir. bkz. Nevizade Atâi, Şakaik-i Nu'maniye ve Zeylleri, II, nşr. Abdülkadir Özcan, İstanbul, Çağrı Yayınları, 1989, s.315.

92 Cahit Baltac1, XV-XVI. Astrlarda Osmanlı Medreseleri, İstanbul, Marmara Üniversitesi İlahiyat Fakültesi Vakfı Yayınları, 2005, s.743.

93 Mustafa b. Hüseyin b. Sinan inşa olunup, Zal Mahmud Paşa'ya ait olan ikinci medreseye atanan ilk müderristir. bkz. a.g.e, s. 665.

94 Baltac1, a.g.e, s.743.

95 Atâî, s. 297.

96 Atâî, s. 501.

97 Baltac1, s. 744.

98 Atâî, s. 570.

99 Atâî, s. 646.

100 Atâî, s. 439.

101 Atâî, s. 405.

102 Atâî, s. 512. 


\begin{tabular}{|c|c|}
\hline Abdurrahman Efendi ${ }^{103}$ & $999(1590)$ \\
\hline Abdülhalim Efendi ${ }^{104}$ & $999(1590)$ \\
\hline Derviş Mehmed Çelebi ${ }^{105}$ & $\begin{array}{c}1000-1003 \\
(1591-1594)\end{array}$ \\
\hline Mustafa Efendi ${ }^{106}$ & 1003 (1594) \\
\hline Mubassirzade Mehmed ${ }^{107}$ & $\begin{array}{c}1005-1006 \\
(1596-1597)\end{array}$ \\
\hline Celâlzade ${ }^{108}$ & $1006(1597)$ \\
\hline Celladzade Hüsameddin ${ }^{109}$ & $\begin{array}{c}1006-1010 \\
(1597-1601)\end{array}$ \\
\hline $\begin{array}{l}\text { Seyyid Mehmed b. Seyyid Mehmed } \\
\text { (Şerifî Mehmed Efendi) }\end{array}$ & $\begin{array}{c}1006-1008 \\
(1597-1599)\end{array}$ \\
\hline Ali Çelebizade Abdullah ${ }^{111}$ & $\begin{array}{l}1008--1009 \\
(1599-1600)\end{array}$ \\
\hline Ahmed Efendi ${ }^{112}$ & $\begin{array}{c}1009-1012 \\
(1600-1603)\end{array}$ \\
\hline Ahmed Efendi ${ }^{113}$ & $1010(1601)$ \\
\hline Abdülkerim Efendi ${ }^{114}$ & $\begin{array}{c}1011-1013 \\
(1602-1604)\end{array}$ \\
\hline Muharrem Efendi ${ }^{115}$ & $\begin{array}{c}1014-1016 \\
(1605-1607)\end{array}$ \\
\hline
\end{tabular}

103 Atâî, s. 527.

104 Atâî, s. 445.

105 Atâî, s. 562.

106 Atâî, s. 620.

107 Atâî, s. 409.

108 Baltac1, a.g.e, s. 743.

109 Atâî, s. 588.

110 Atâî, s. 742.

111 Atâî, s. 725

112 Atâî, s. 683.

113 Atâî, s. 532.

114 Atâî, s. 718.

115 Atâî, s. 633. 


\begin{tabular}{|c|c|c|}
\hline Muhteşem Ridvan Efendi ${ }^{116}$ & $\begin{array}{c}1015-1018 \\
(1606-1609)\end{array}$ & \\
\hline Mehmed Efendi ${ }^{117}$ & $\begin{array}{c}1018-1019 \\
(1609-1610)\end{array}$ & \\
\hline $\begin{array}{l}\text { Mehmed b. Emrullah Mehmed b. Muhyiddin } \\
\text { el-Hüseyni (Seyyid Mehmed Çelebi) }\end{array}$ & $\begin{array}{c}1019-1021 \\
(1610-1612)\end{array}$ & \\
\hline Abdülbaki Efendi (Bahrizade Dürri Çelebi) $)^{119}$ & $\begin{array}{c}1019-1021 \\
(1610-1612)\end{array}$ & \\
\hline Derviş Mehmed Çelebi ${ }^{120}$ & $1021(1612)$ & \\
\hline Mustafa Efendi (Baki Efendi Muslusu) $)^{121}$ & $1021(1612)$ & \\
\hline Ali Edîbî (Bakkalzade Efendi) ${ }^{122}$ & $\begin{array}{c}1024-1025 \\
(1615-1616)\end{array}$ & \\
\hline Tevfikzade Ahmed Çelebi ${ }^{123}$ & $\begin{array}{c}1024-1028 \\
(1615-1619)\end{array}$ & \\
\hline Gül Mustafa Efendi ${ }^{124}$ & $\begin{array}{c}1025-1026 \\
(1616-1617)\end{array}$ & \\
\hline Nasrullah Efendi ${ }^{125}$ & $\begin{array}{c}1026-1028 \\
(1617-1619)\end{array}$ & \\
\hline Derviş Efendi ${ }^{126}$ & $1028(1619)$ & \\
\hline Fenarizade Şeyhi Mehmed Efendi ${ }^{127}$ & $\begin{array}{c}1028-1029 \\
(1619-1620)\end{array}$ & 60 akçe \\
\hline Hüseyin Efendi ${ }^{128}$ & $\begin{array}{c}1029-1032 \\
(1620-1623)\end{array}$ & \\
\hline
\end{tabular}

116 Atâî, s. 666.

117 Atâî, s. 694.

118 Atâî, s. 562.

119 Atâî, s. 579.

120 Atâî, s. 560.

121 Atâî, s. 647.

122 Atâî, s. 630.

123 Şeyhî, III, s. 102.

124 Şeyhî, s. 108.

125 Atâî, II, s. 754.

126 Atâî, s. 753.

127 Şeyhî, III, s.121.

128 Atâî, II, s. 749. 


\begin{tabular}{|c|c|c|}
\hline Mektubî Asamm Derviş Efendi ${ }^{129}$ & $\begin{array}{c}1033-1034 \\
(1624-1625)\end{array}$ & \\
\hline Ahmed Efendi ${ }^{130}$ & $\begin{array}{c}1032-1034 \\
(1623-1625)\end{array}$ & \\
\hline Ahmed Efendi ${ }^{131}$ & $\begin{array}{c}1032-1034 \\
(1623-1625)\end{array}$ & 60 akçe \\
\hline Bostanzade Ahmed Efendi ${ }^{132}$ & $\begin{array}{c}1034-1038 \\
(1625-1629)\end{array}$ & \\
\hline Hamza Efendi ${ }^{133}$ & $\begin{array}{c}1034-1035 \\
(1625-1626) \\
\end{array}$ & 60 akçe \\
\hline Hüsrev Paşa İmamı Mustafa Efendi ${ }^{134}$ & $\begin{array}{c}1038-1040 \\
(1629-1631)\end{array}$ & \\
\hline Kebirî Mehmed Efendi ${ }^{135}$ & $\begin{array}{c}1039-1040 \\
(1630-1631)\end{array}$ & \\
\hline Mantıkî Ahmed Efendi ${ }^{136}$ & $1040(1631)$ & \\
\hline Ankaravî Es'ad Efendi ${ }^{137}$ & $\begin{array}{c}1040-1042 \\
(1631-1633)\end{array}$ & \\
\hline Ece Yakub Efendi ${ }^{138}$ & $\begin{array}{c}1040-1042 \\
(1631-1633)\end{array}$ & \\
\hline Karamanî Süleyman Efendi ${ }^{139}$ & $\begin{array}{c}1042-1045 \\
(1633-1636)\end{array}$ & \\
\hline Ebusuud Efendi ${ }^{140}$ & $\begin{array}{c}1045-1050 \\
(1636-1641)\end{array}$ & \\
\hline Kirli Hanımzade Hasan Efendi ${ }^{141}$ & $\begin{array}{c}1042-1049 \\
(1633-1640)\end{array}$ & \\
\hline
\end{tabular}

129 Şeyhî, III, s.36.

130 Şeyhî, s. 45

131 Atâî, II. s.700.

132 Şeyhî, III, s. 322.

133 Atâî, II, s.701.

134 Şeyhî, III, s.206.

135 Şeyhî, s. 202.

136 Şeyhî, s. 23.

137 Şeyhî, s. 242.

138 Şeyhî, s. 381.

139 Şeyhî, s. 25.

140 Şeyhî, s. 387.

141 Şeyhî, s. 213. 


\begin{tabular}{|c|c|}
\hline Ahizade Mehmed Efendi ${ }^{142}$ & $1049(1640)$ \\
\hline Esseyid Abdurrahman Efendi ${ }^{143}$ & $\begin{array}{c}1050-1051 \\
(1641-1642)\end{array}$ \\
\hline Sadreddinzade Feyzullah Efendi ${ }^{144}$ & $\begin{array}{c}1050-1053 \\
(1641-1644)\end{array}$ \\
\hline Hacı Yusufzade Zamirî Ahmed Efendi ${ }^{145}$ & $\begin{array}{c}1053-1056 \\
(1644-1647)\end{array}$ \\
\hline Hoca Fesadzade Seyyid Ahmed ${ }^{146}$ & $\begin{array}{c}1051-1054 \\
(1642-1645)\end{array}$ \\
\hline Dayezade Mustafa Efendi ${ }^{147}$ & $\begin{array}{c}?-1057 \\
(?-1648)\end{array}$ \\
\hline Mehmed Efendi ${ }^{148}$ & $\begin{array}{c}1054-1057 \\
(1645-1648)\end{array}$ \\
\hline Riyâzizade Abdüllatif Efendi 149 & $1058(1649)$ \\
\hline Erzurumî İbrahim Efendi ${ }^{150}$ & $\begin{array}{c}1058-1060 \\
(1649-1651)\end{array}$ \\
\hline Mahmudzade Zeynelabidin ${ }^{151}$ & $\begin{array}{c}1058-1060 \\
(1649-1651)\end{array}$ \\
\hline Hac1 Mustafa Efendi ${ }^{152}$ & $\begin{array}{c}1060-1062 \\
(1651-1653)\end{array}$ \\
\hline Avarzade Mes'ud Efendi ${ }^{153}$ & $\begin{array}{c}1060-1061 \\
(1651-1652)\end{array}$ \\
\hline Seyyid Abdullah Efendi ${ }^{154}$ & $\begin{array}{c}1060-1065 \\
(1651-1656)\end{array}$ \\
\hline
\end{tabular}

142 Şeyhî, s. 98.

143 Şeyhî, s. 413.

144 Şeyhî, s. 244.

145 Şeyhî, s. 141.

146 Şeyhî, s. 354.

147 Şeyhî, s. 198.

148 Şeyhî, s. 311.

149 Şeyhî, s. 345.

150 Şeyhî, s. 189.

151 Şeyhî, s. 274.

152 Şeyhî, s. 304.

153 Şeyhî, s. 451.

154 Şeyhî, s. 353. 


\begin{tabular}{|c|c|}
\hline Muhteşem Emirî Seyyid Mehmed ${ }^{155}$ & $1061(1652)$ \\
\hline Naib Ömer Efendi ${ }^{156}$ & $\begin{array}{c}1061-1063 \\
(1652-1654)\end{array}$ \\
\hline Mustafa Efendi ${ }^{157}$ & $\begin{array}{c}1065-1066 \\
(1656-1657)\end{array}$ \\
\hline Hüseyin Paşazade İbrahim Efendi ${ }^{158}$ & $1066(1657)$ \\
\hline İlahizade Mehmed Efendi ${ }^{159}$ & $\begin{array}{c}1067-1068 \\
(1658-1659)\end{array}$ \\
\hline Abdülmuttalib Efendi ${ }^{160}$ & $1068(1659)$ \\
\hline ? Abdülbaki Efendi ${ }^{161}$ & $\begin{array}{c}1069-1072 \\
(1660-1663)\end{array}$ \\
\hline Şeyhilüslam Ankaravî Mehmed Efendi ${ }^{162}$ & $1072(1663)$ \\
\hline Bostanzade Ebubekir Efendi ${ }^{163}$ & $\begin{array}{c}1072-1074 \\
(1663-1665)\end{array}$ \\
\hline Beyazizade Ahmed Efendi ${ }^{164}$ & $\begin{array}{c}1074-1075 \\
(1665-1666)\end{array}$ \\
\hline Edirneli Ahmed Efendi 165 & $\begin{array}{c}1075-1076 \\
(1666-1667)\end{array}$ \\
\hline K1z Ali Efendi ${ }^{166}$ & $\begin{array}{c}1076-1078 \\
(1667-1669)\end{array}$ \\
\hline Sar1 Abdullahzade Abdurrahman Efendi ${ }^{167}$ & $\begin{array}{c}?-1075 \\
(?-1666)\end{array}$ \\
\hline
\end{tabular}

155 Şeyhî, s. 375.

156 Şeyhî, s. 291.

157 Şeyhî, s. 464.

158 Şeyhî, s. 530.

159 Şeyhî, s. 430.

160 Şeyhî, s. 320 .

161 Şeyhî, s. 468.

162 Şeyhî, s. 544.

163 Şeyhî, s. 389.

164 Şeyhî, s. 535.

165 Şeyhî, s. 420.

166 Şeyhî, s. 393.

167 Şeyhî, s.370. 


\begin{tabular}{|c|c|c|}
\hline Sarı Osman Efendi 168 & $\begin{array}{c}1076-1079 \\
(1667-1670)\end{array}$ & \\
\hline Musazade Abdülbaki Efendi ${ }^{169}$ & $1081(1672)$ & \\
\hline Şârih-i Mülteka Seyyid Mehmed Efendi ${ }^{170}$ & $\begin{array}{c}1078-1081 \\
(1669-1672)\end{array}$ & \\
\hline Hekimbaşızade Yahya ${ }^{171}$ & $\begin{array}{c}1081-1084 \\
(1672-1675)\end{array}$ & \\
\hline Rifkî Mehmed Efendi ${ }^{172}$ & $\begin{array}{c}1081-1084 \\
(1672-1675)\end{array}$ & \\
\hline Şeyhülislam Mehmed Efendi ${ }^{173}$ & $1084(1675)$ & 60 akçe \\
\hline Evliya Mehmed Efendi ${ }^{174}$ & $\begin{array}{c}1084-1086 \\
(1675-1677)\end{array}$ & \\
\hline Şeyhilüslam Ali Efendi Biraderi Ebubekir ${ }^{175}$ & $\begin{array}{c}1085-1086 \\
(1676-1677)\end{array}$ & \\
\hline Muharremzade Mehmed Efendi ${ }^{176}$ & $\begin{array}{c}1086-1088 \\
(1677-1679)\end{array}$ & \\
\hline Mü’minzade Mehmed ${ }^{177}$ & $\begin{array}{c}1086-1089 \\
(1677-1680)\end{array}$ & \\
\hline Şamî Abdülbaki Efendi ${ }^{178}$ & $1088(1679)$ & \\
\hline Derviş Hattatzade Abdullah Efendi ${ }^{179}$ & $\begin{array}{c}1089-1091 \\
(1680-1682)\end{array}$ & \\
\hline Davudzade Mustafa Efendi ${ }^{180}$ & $\begin{array}{c}1091-1092 \\
(1682-1683)\end{array}$ & \\
\hline
\end{tabular}

168 Şeyhî, s.454.

169 Şeyhî, s.518.

170 Şeyhî Mehmed Efendi, Şakaik-i Nu'maniye ve Zeylleri, IV, nşr. Abdülkadir Özcan, İstanbul, Çağrı Yayınları, 1989, s. 71.

171 Şeyhî, s. 267.

172 Şeyhî, s. 166.

173 Şeyhî, s. 651.

174 Şeyhî, s.190.

175 Şeyhî, III, s.449.

176 Şeyhî, IV, s.185.

177 Şeyhî, s. 23.

178 Şeyhî, III, s. 438-439.

179 Şeyhî, IV, s. 262-263.

180 Şeyhî, s.7. 


\begin{tabular}{|c|c|}
\hline Şeyhülislâm Menteşzade Abdurrahim Efendi ${ }^{181}$ & $\begin{array}{c}1092-1094 \\
(1683-1685)\end{array}$ \\
\hline Şaranîzade Mehmed Ramazan Efendi ${ }^{182}$ & $\begin{array}{c}1091-1094 \\
(1682-1685)\end{array}$ \\
\hline Şemseddinzade Mustafa Efendi ${ }^{183}$ & $\begin{array}{c}1091-1099 \\
(1682-1690)\end{array}$ \\
\hline $\begin{array}{c}\text { Nakibüleşraf Nefeszade Seyyid Abdurrahman } \\
\text { Efendi }^{184}\end{array}$ & $\begin{array}{c}1091-1099 \\
(1682-1690)\end{array}$ \\
\hline Davudzade İbrahim Efendi ${ }^{185}$ & $\begin{array}{c}1094-1097 \\
(1685-1688)\end{array}$ \\
\hline Uşakî Mustafa Efendi ${ }^{186}$ & $\begin{array}{c}1094-1097 \\
(1685-1688)\end{array}$ \\
\hline Hamidzade Abdullah Efendi ${ }^{187}$ & $\begin{array}{c}1097-1099 \\
(1688-1690)\end{array}$ \\
\hline Fazıl Kara Halil Efendi ${ }^{188}$ & $\begin{array}{c}1099-1100 \\
(1690-1691)\end{array}$ \\
\hline Nifî İbrahim Efendi ${ }^{189}$ & $\begin{array}{c}1099-1102 \\
(1690-1693)\end{array}$ \\
\hline Emrullah Efendi ${ }^{190}$ & $\begin{array}{c}1100-1101 \\
(1691-1692)\end{array}$ \\
\hline $\begin{array}{c}\text { Nakibülesraf Sahafşeyhizade Seyyid Mehmed } \\
\text { Efendi }^{191}\end{array}$ & $\begin{array}{c}1101-1103 \\
(1692-1694)\end{array}$ \\
\hline Abdurrahimzade Şeyhi Mehmed Efendi ${ }^{192}$ & $\begin{array}{c}1103-1106 \\
(1694-1697)\end{array}$ \\
\hline
\end{tabular}

181 Şeyhî, s. 393.

182 Şeyhî, s. 78.

183 Şeyhî, s.89.

184 Şeyhî, s. 125 .

185 Şeyhî, s. 375.

186 Şeyhî, s.26.

187 Şeyhî, s. 507. Zal Paşa Sultani Medresesi'nde müderris iken Kudüs Kadısı oldu. bkz. a.g.e, s.50.

188 Şeyhî, s. 329.

189 Şeyhî, s. 304.

190 Şeyhî, s. 187.

191 Şeyhî, s. 398.

192 Şeyhî, s. 152. 


\begin{tabular}{|c|c|c|}
\hline Es'adzade İmamı Mehmed Efendi ${ }^{193}$ & $\begin{array}{c}1104-1106 \\
(1695-1697)\end{array}$ & \\
\hline Abdurrahimzade Şeyhi Mehmed Efendi ${ }^{194}$ & $\begin{array}{c}1106-1110 \\
(1697-1701)\end{array}$ & \\
\hline İvazzade İsmail Efendi ${ }^{195}$ & $\begin{array}{c}1106-1112 \\
(1697-1703)\end{array}$ & \\
\hline Mustafa Efendi ${ }^{196}$ & $\begin{array}{c}1111-1114 \\
(1702-1705)\end{array}$ & \\
\hline Hocazade Seyyid Ömer Efendi ${ }^{197}$ & $1112(1703)$ & \\
\hline Abdurrahimzade Ahmed Efendi ${ }^{198}$ & $\begin{array}{c}1111-1115 \\
(1702-1706)\end{array}$ & \\
\hline Mustafa Efendi ${ }^{199}$ & $\begin{array}{c}1115-1116 \\
(1706-1707)\end{array}$ & \\
\hline Abdülkerim Refdi Mehmed Efendi 200 & $\begin{array}{c}?-1116 \\
(?-1707)\end{array}$ & 60 akçe \\
\hline Ağazade Seyyid Mehmed Efendi ${ }^{201}$ & $\begin{array}{c}1116-1118 \\
(1707-1709)\end{array}$ & \\
\hline $\begin{array}{l}\text { Müfettiş İbrahim Efendi biraderzadesi Abdullah } \\
\qquad \text { Efendi }^{202}\end{array}$ & $\begin{array}{c}1117-1118 \\
(1708-1709)\end{array}$ & 60 akçe \\
\hline Es'adzade Faiz Seyyid Abdürrahim Efendi ${ }^{203}$ & $\begin{array}{c}1118-1121 \\
(1709-1712)\end{array}$ & \\
\hline Nefeszade Seyyid Mehmed Aziz Efendi ${ }^{204}$ & $\begin{array}{c}1121-1123 \\
(1712-1714)\end{array}$ & 60 akçe \\
\hline Emin Mehmed Efendi 205 & $\begin{array}{c}1122-1123 \\
(1713-1714)\end{array}$ & 60 akçe \\
\hline
\end{tabular}

193 Şeyhî, s. 87.

194 Şeyhî, s. 152.

195 Şeyhî, s. 257.

196 Şeyhî, s. 519.

197 Şeyhî, s. 449.

198 Şeyhî, s. 511.

199 Şeyhî, s. 519.

200 Şeyhî, s. 523.

201 Şeyhî, s. 639.

202 Şeyhî, s. 584.

203 Şeyhî, s. 603.

204 Şeyhî, s. 491.

205 Şeyhî, s. 608. 


\begin{tabular}{|c|c|c|}
\hline Kami Mehmed Efendi ${ }^{206}$ & $1122(1713)$ & 60 akçe \\
\hline Mehmed Emin Efendi ${ }^{207}$ & $1124(1715)$ & \\
\hline Saray Hocası Mustafa Efendi ${ }^{208}$ & $\begin{array}{c}1123-1126 \\
(1714-1717)\end{array}$ & \\
\hline La' lizade Seyyid Abdullah Efendi ${ }^{209}$ & $\begin{array}{c}1126-1128 \\
(1717-1719)\end{array}$ & 60 akçe \\
\hline $\begin{array}{l}\text { Abdullah Efendi Biraderzadesi Mustafa Efendi } \\
\qquad 210\end{array}$ & $\begin{array}{c}1125-1129 \\
(1716-1720)\end{array}$ & 60 akçe \\
\hline Müfettiş Kâtibi Ahmed Efendi ${ }^{211}$ & $1129(1720)$ & \\
\hline Haffafzade İbrahim Efendi ${ }^{212}$ & $1129(1720)$ & \\
\hline Vânî Hafidî Seyyid Mehmed Efendi ${ }^{213}$ & $\begin{array}{c}1131-1132 \\
(1722-1723)\end{array}$ & 60 akçe \\
\hline Kürd Ali Efendi ${ }^{214}$ & $\begin{array}{c}1132-1134 \\
(1722-1725)\end{array}$ & 60 akçe \\
\hline İmam-1 Sultanî Abdullah Efendi ${ }^{215}$ & $\begin{array}{c}1137-1138 \\
(1728-1729)\end{array}$ & 60 akçe \\
\hline
\end{tabular}

\section{Osmanlı Devleti'nin Son Dönemi’nde Şah Sultan ve Zal Mahmud Paşa Vakfi}

Osmanlı Arşivi'nde yer alan vesikalar ile Evkaf Nezareti tarafindan tutulan muhasebe defterlerinden vakfın varlığını Cumhuriyet Dönemi'ne kadar sürdürdüğü anlaşılmaktadır. Muhasebe kayıtlarını inceleme firsatını bulan Mustafa Güler, her sene yapılan hesaplamalara göre bahsedilen tahsislerde değişiklikler olduğunu, 1117-1119 (1705-1707) senelerinde yapılan muhasebeye göre vakfin toplam gelirinin 887.626 akçe olup, bunun 843.375 akçesinin masraflara harcandığını, bu tutarın 576.760 akçesini görevlilere diğer 266.715 akçesini ise tamir

206 Şeyhî, s. 568.

207 Zal Mahmud Paşa medresesinde müderris iken Diyarbekir kadısı oldu. bkz. a.g.e, s. 451.

208 Şeyhî, s. 561.

209 Şeyhî, s. 624.

210 Şeyhî, s. 542.

211 Şeyhî, s. 403.

212 Şeyhî, s. 645.

213 Şeyhî, s. 500.

214 Şeyhî, s. 520.

215 Şeyhî, s. 642. 
giderleri için harcanmış olduğunu belirtmiştir. Başlangıçta görevlilere yapılan harcamaya göre 150 senede vakfin gelirlerinin üç kat arttığını fakat, bu artışla beraber akçenin değer kaybettiği de hesaba katılırsa bunun gerçek bir artış olmadığını ifade etmiştir. ${ }^{216}$

Zal Mahmud Paşa ile Şah Sultan'ın vakıfları zor durumda olan hazineye yardım için imdadiye olarak her Muharrem ayında belli bir miktar ödeme yapmaktaydı. Ulaşabildiğimiz ilk kayıt, sefer imdadiyesi olarak verilmiştir. ${ }^{217} 1100$ (1689) yılına aittir ve İstanbul'un Venedik tehlikesi ile karşı karşıya kalıp, pahalılığın ortaya çıktığı, hazinenin sıkıntıya girdiği döneme denk gelmektedir. ${ }^{218}$ İmdadiye ile ilgili kayitlardan ulaşabildiğimiz ikinci vesika ise 1218 (1804) tarihlidir. Bu vesikadan her sene Muharrem ayında 100.000 akçe ödeme yapıldığ 1 anlaşılmaktadır. $^{219}$

1774 yılından sonra Rusya'nın Karadeniz'in kuzeyinde uyguladığı politikadan ötürü bu bölgeden Osmanlı Devleti'ne çeşitli göç dalgaları yaşanmıştır. Bunların en büyügü ise 1859-1862 yılında gerçekleşmiştir. ${ }^{220} \mathrm{Bu}$ göç dalgaları sırasında 1860 yılında Nogaylar ve Kıpçak kabilesinden olan ve İstanbul'a muhacir olarak gelen iki yüz seksen kişi Şah Sultan ve Zal Mahmud Paşa Külliyesi içerisindeki medreselerde iskân ettirilmiştir. Kırk günden beri tayinat verilmediğinden ötürü fakirlik ve ihtiyaç içinde bulunan bu muhacirlere bir an önce ödeme yapılması lüzumundan bahseden vesikadan medreselerin muhacirleri konuk ettiği anlaşılmaktadır. ${ }^{221}$

Osmanlı Arşivi'nde bulunan bir vesikadan medrese içerisinde fuzuli ikamette bulunan kişilerin çıkarılarak medresenin müderris Mehmed Fevzi Efendi’ye teslim edilmesi gerekliliğinden bahsedilmektedir. $\mathrm{Bu}$ bize medresedeki tedrisatın 1909 tarihinde hala devam ettiğini göstermektedir. Ayrıca 1914 tarihinde teftiş heyeti tarafindan yapılan bir rapor bulunmaktadır. Raporda, caminin altındaki odaların kati surette öğrencilerin iskânı için uygun olmadığı, sadece dört odanın iskâna elverişli olduğu belirtilmiştir. Fakat diğer cephedeki odaların uygun şekilde onarımı yapılırsa talebelerin yaşayabileceği duruma geleceği belirtilmiş̧iri. ${ }^{222}$

216 Güler, a.g.m, s. 217.

217 BOA, AE. SSÜL. II, 19/1994, 29 Za 1100/ 14 Ekim 1689.

218 Abdülkadir Özcan, "Mehmed IV", DİA, XXVIII, Ankara, 2003, s.415.

219 BOA, C. EV/447/22640, 29 Za 1218/ 10 Nisan 1804.

220 Derya, Derin Paşaoğlu, “28957 No’lu İrade-i Dahiliye’ye göre Nogay Muhacirleri üzerine bir değerlendirme”, Kültür Evreni, cilt 3, sayı 10, Ankara, 2011, s.33.

221 BOA, A.MKT.MHM, 175/29, 29 C 1276/ 23 Ocak 1860.

222 Kütükoğlu, a.g.e, s.304. 
Şah Sultan ve Zal Mahmud Paşa'nın medreselerinin 3 Mart 1924'te Türkiye Büyük Millet Meclisi'nde Tevhid-i Tedrisat Kanununun kabul edilerek medreselerin kapanmasına kadar eğitim-öğretim hayatına devam ettiği düşünülmektedir. Bununla birlikte Şeriye ve Evkaf Vekaleti'nin 1924'te lav edilmesinden sonra ise, cami Diyanet İşleri Başkanlığı'na bağlanmıştır. Yukarıda bahsedilen vakıf akarları arasında olan külliyenin yakınındaki bina ise günümüze ulaşmamıştır. Ankara'da bulunan dükkânlar ise vakıfların tasfiyesi sürecinde satılmıştır. Filibe ve Pirlepe'de bulunan eserlerin akıbeti hakkında ise maalesef elimizde yeterli bilgi bulunmamaktadır.

Şah Sultan ve Zal Mahmud Paşa'nın 1590 senesinde son halini alan külliyeleri yüzyıllar içerisinde bazı problemlerle karşılaşmış ve çeşitli bakım onarım faaliyetlerine tabi tutulmuştur. Bu problemlerden tespit edebildiklerimizin ilki caminin lağımının denize akmasıdır. Buna mani olunması için yazılan 26 Ağustos 1784 tarihli bir vesika Osmanlı Arşivi'nde mevcut bulunmaktadır. ${ }^{223}$ Caminin tamiri ile ilgili tespit edebildiğimiz en eski vesika 1266 (1850) tarihlidir. ${ }^{224}$ Buna göre harap olan yerlerin ikinci keşfinin yapıldığ fakat henüz tamire başlanmadığ anlaşılmaktadır. Hesaba göre masraf 9.299.5 kuruştur. Söz ettiğimiz vesikanın devamı niteliğindeki 1268 (1852) yılına ait keşf-i sani defteri ise tamiratın başladığını göstermektedir. ${ }^{225}$ Bununla birlikte son tamirden 21 y1l sonra yani, 1290 (1873) yılında yeniden onarım görmesi gerektiği vesikalardan anlaşılmaktadır. ${ }^{226}$ Bunu takip eden diğer bir vesika ise bu onarımın $7.976^{227}$ kuruş tutacak masrafı ile ilgilidir. ${ }^{228}$

Buna ilaveten elimizde bulunan 1310 (1893) tarihli belgeden, caminin minaresine yıldırım isabet ettiği anlaşılmaktadır. Tehlikeli şekilde zedelenen minare, 1299 (1882) tarihinde yıktırılmıştır. Bu yıkım için 10.358 kuruş sarf edilmiştir. Ayrıca, minare ile birlikte Şah Sultan ile Zal Mahmud Paşa'nın medfun olduğu türbenin harap yerlerinin de onarılması gerektiği anlaşılmaktadır. Diğer bazı yerlerin de eklenmesiyle onarımların tutarı toplam 69.756 kuruş olarak belirlenmiştir. ${ }^{229}$ Minarenin yıktırılmasından sonra yeniden inşası için bir minare planı çizilmiştir.

223 Bkz. BOA, AE.SABH.I./33-2455, 9 L 1198/ 26 Ağustos 1784.

224 BOA, A.AMD.18-85, 15 C 1266, 28 Nisan 1850.

225 Ayrıntılı bilgi için bkz. BOA, EV.d./32390, 29 M 1268/ 24 Kasım 1851.

226 BOA, İ.DH., 690/48198, 22 Ş 1291/4 Ekim 1874.

$227 \mathrm{Bu}$ sayı daha sonra karşılaştığımız iki vesikada 69.759 olarak geçmektedir. Bkz. BOA, BEO.1376/103150/001, 18 Ca 1317/5 Ekim 1897.

228 Ayrıntılı bilgi için bkz. BOA, İ.DH., 717/50088, 21 M 1293/17 Şubat 1876.

229 BOA, İ.EV.2/80, 12 Ş 1310/1 Mart 1893. 
10 Temmuz 1894 tarihinde İstanbul'da öğleden sonra saat 12'yi 24 dakika geçe $3 \mathrm{kez}$ şiddetli bir şekilde deprem yaşanmıştır. Bu sarsıntılar sonucunda tahribatın tamamı gerçekleşmiştir. ${ }^{230} \mathrm{Bu}$ yüzden onarım planı dahilinde olan Şah Sultan ve Zal Mahmud Paşa Camii'nin depremden dolayı tamir olunamadığı ve çalışmaya ara verildiği 5 Ekim 1897 tarihli bir belgeden anlaşılmaktadır. Yani yaşanan depremden ötürü caminin tamiratına yaklaşık dört sene ara verilmiştir. ${ }^{231}$ Ancak, 1898 tarihli bir belgeden; deprem nedeniyle külliyenin caddeye bakan duvarlarında oluşan hasarlar ve yine külliyeye komşu olan III. Selim'in kız kardeşi Şah Sultan Camii ve Türbesi'nin de harap olan yerlerinin onarılması için heyet-i fenniye tarafından yeni bir keşif yapıldığı ve buna binaen iki baninin eserleri için toplam masrafin 66.660 kuruş 30 para olarak belirlendiği görülmektedir. ${ }^{232}$ Devamındaki iki vesika ise bu işlerin maliye ve bürokrasi kısmının takibi ile alakalıdır. ${ }^{233}$

Sonuç olarak, bu çalışma ile tarihî kaynak değeri yüksek olan vakfiyeler kullanılarak, bir dönemin sosyo-kültürel yönlerini aydınlatmakla birlikte mahallî tarih araştırmalarına ve tarihî şahsiyetlerin tanıtılmasına katkı sağlanmaya çalışılmıştır. Ana malzememizi teşkil eden vakfiyeden hareketle, 16. yüzyılda yaşamış ve kurmuş oldukları vakıflar sayesinde isimlerini, bugüne kadar yaşatmış olan Şah Sultan ve Zal Mahmud Paşa tanıtıldığı gibi diğer arşiv belgeleri ve kaynaklar 1şı̆̆ında bu aileye ait elde edilen yeni bilgiler de aktarılmıştır.

Osmanlılar'ın İstanbul'da yaptırdığı ilk mimari kompleks olan Eyüp Sultan Külliyesi'nin çevresi, hanedan üyesi kadınlar, devlet ricâli ve halk kitlelerinin Ebû Eyyûb'un şefaatini kazanmak için burayı son istirahatgâh olarak seçmeye başlamaları üzerine kısa sürede gelişmiştir. Biri Osmanlı hanedanının kadın üyesi, diğeri de devletin en üst kadrosunda vezir olarak görev yapan bu iki isim, mallarının bir kısmını vakfederek halkın istifadesine sunmuşlar, Eyüp semtine yeni eserler kazandırmışlardır. Defterdar ve Zalpaşa caddeleri arasındaki Zal Mahmud Paşa Külliyesi içinde barındırdığı medreseleri ile Eyüp'de eğitim ve kültür faaliyetlerine hız kazandırmıştır. Bu noktadan hareketle belgelere yansıdığı ölçüde kişilerin hayatları, aileleri hakkında bilgi verildiği gibi vakıf kuran isimlerin vakıfları da tanıtılmıştır. Daha önce yapılan çalışmalarda bu aileden

230 Hamiyet Sezer, “1894 İstanbul Depremi Hakkımda Bir Rapor Üzerine İnceleme”, Ankara Üniversitesi Dil ve TarihCoğrafya Fakültesi Tarih Bölümü Tarih Araştırmaları Dergisi, sayı 29, cilt 18, Ankara, 1996, s.171.

231 BOA, BEO, 001376.103150.001, 18 Ca 1317/5 Ekim 1897.

232 BOA, İ.EV.18/48.001-002, 8 Z 1315/ 31 Mart 1898.

233 Ayrıntılı bilgi için bkz. BOA, İ.EV.23/12, 1 Ca 1317/ 7 Eylül 1899; BOA, BEO, 1841/138055, 27 M 1320/ 6 May1s 1902. 
bahseden kısımların noksan yönleri tamamlandığı gibi elde edilen yeni bilgilerle de karanlıkta kalan noktalara 1şık tutulmuştur. Örnek göstermek gerekirse, Şah Sultan ile Zal Mahmud Paşa'nın aynı gün birlikte vefat etmedikleri, on üç gün ara ile hayatlarını kaybettikleri gerçeği ortaya çıkmış, yanlış bilinen ölüm tarihleri vakfiyeden istifadeyle tashih edilmiştir. Ayrıca Zal Mahmud Paşa'nın bir oğlu olduğu, hangi vazife ile meşgul olduğu bilgisi de arşiv belgeleri ile gün yüzüne çıkarılmıştır. Bununla birlikte yine diğer çalışmalarda yer almayan Şah Sultan'ın çeyiz listesi ile medreselerde görev alan müderrisler ve görev aralıklarının bir arada verilmesi çalışmalara getirilen yeniliklerden birkaçıdır.

Şah Sultan ve Zal Mahmud Paşa'ya ait külliyenin cami, medrese, çeşme, türbe şeklinde kurulduğu görülmektedir. Bununla birlikte Paşa'nın Ankara ve Pirlepe'de de vakıfları bulunmaktadır.

İki eşin vakıfları birbirinden ayrı olarak kurulmalarına rağmen daha sonra Zal Mahmud Paşa'nın vakfının mali yönden zor duruma düşmesiyle beraber, Şah Sultan'ın kurmuş olduğu vakıfla birleştirilerek tek çatı altında toplandığ görülmüştür. Eyüp'te bulunan cami, medrese, çeşme ve türbe bugün hala ayaktadır. Ancak, medrese kısmı sahaflar ve güzel sanat atölyeleri için kullanıma açılmıştır. Ankara ve Pirlepe'deki eserlerin durumu hakkında yeterli bilgi bulunmamaktadır. Sınırları gereğince araştırmamız Şah Sultan ve Zal Mahmud Paşa vakıflarına yönelik genel bir araştırma niteliğindedir. Arşivlerde yeni malzemelerin ortaya çıkması, muhasebe kayıtları, şahsiyet kayıtları ve atik esas evraklarının kullanılarak geniş çerçeveli ve uzun süreli bir çalışma yapılması durumunda bu alanda daha kapsamlı eserlerin ortaya çıkacağı şüphesizdir. 


\section{Kaynakça}

\section{Arşiv Belgeleri}

5 Numaralı Mühimme Defteri (973/1565-1566), I, haz. Hacı Osman Y1ldırım vd., Ankara, Osmanlı Arşivi Daire Başkanlığı Yayınları, 1994.

6 Numaralı Mühimme Defteri (972/1564-1565), I, haz. Hacı Osman Yıldırım vd., Ankara, Osmanlı Arşivi Daire Başkanlığı Yayınları, 1995.

Bostancı, Muharrem, "19 Numaralı Mühimme Defteri", (Yayımlanmamış Yüksek Lisans Tezi), İstanbul Üniversitesi Sosyal Bilimler Enstitüsü, İstanbul, 2002.

Günay, Musa, "55 Numaralı Mühimme Defteri (992-993/ 1584-1585)”, (Yayımlanmamış Yüksek Lisans Tezi), 19 Mayıs Üniversitesi Sosyal Bilimler Enstitüsü, Samsun, 1996.

İstanbul Kadı Sicilleri Üsküdar Mahkemesi: H.1000, M. 1592, cilt 10, İstanbul, İSAM Yayınları, 2008.

BOA, EV.VKF, 20/25, 29 Z 1002/15 Eylül 1594.

BOA, A.DVNS.MHM.d., 74/214, 18 S 1005/ 11 Ekim 1596.

BOA, AE. SSÜL. II, 19/1994, 29 Za 1100/ 14 Ekim 1689.

BOA, C. EV, 28/1370, 23 Z 1118/ 28 Mart 1707.

BOA, AE.SMST.III., 130/10104, 29 Za 1183/ 25 Nisan 1770.

BOA, AE.SABH.I./33-2455, 9 L 1198/ 26 Ağustos 1784.

BOA, C. EV/447/22640, 29 Za 1218/ 10 Nisan 1804

BOA, A.AMD.18-85, 15 C 1266, 28 Nisan 1850.

BOA, EV.d./32390, 29 M 1268/ 24 Kasim 1851.

BOA, A.MKT.MHM, 175/29, 29 C 1276/ 23 Ocak 1860.

BOA, İ.DH., 717/50088, 21 M 1293/17 Şubat 1876.

BOA, İ.EV.2/80, 12 Ş 1310/1 Mart 1893.

BOA, BEO.1376/103150/001, 18 Ca 1317/5 Ekim 1897.

BOA, İ.EV.18/48.001-002, 8 Z 1315/ 31 Mart 1898.

BOA, İ.EV.23/12, 1 Ca 1317/ 7 Eylül 1899.

BOA, BEO, 1841/138055, 27 M 1320/ 6 May1s 1902.

BOA, İ.DH., 690/48198, 22 Ş 1291/4 Ekim 1874. 
BOA, TSMA.d,7859.0003, 29 Z 969/ 30 Ağustos 1562.

BOA, TSMA.d,7859.0006, 29 Z 969/ 30 Ağustos 1562.

BOA, TSMA.d,7859.0002.00, 29 Z 969/ 30 Ağustos 1562

BOA, TSMA.d,7859.0005.00, 29 Z 969/ 30 Ağustos 1562.

BOA, TSMA.d,7859.0001.00, 29 Z 969/ 30 Ağustos 1562.

TSMA.e, 4214/682/13, 29 Z 975/ 26 Mayıs 1568.

TSMA.e, 0759/16, 1 N 982/ 15 Aralık 1574.

TSMA.E,0530, ts.

\section{Kitabi Kaynaklar}

Evliya Çelebi, Günümüz Türkçesiyle Evliya Çelebi Seyahatnamesi: İstanbul, 1.cilt-1.kitap, haz. Seyit Ali Kahraman, Yücel Dağlı, İstanbul, Yapı Kredi Yayınlar1, 2003.

Feridun Ahmed Bey, Nüzhet-i Esrarü'l-Ahyâr Der-Ahbâr-ı Sefer-i Sigetvar, haz. Ahmet Arslantürk, Günhan Börekçi, İstanbul, 2012.

Gelibolulu Mustafa Âli, Künhü'l-ahbâr, İstanbul Üniversitesi Nadir Eserler Ktp., nr.5959, vr.437a-437b.

Hâfız Hüseyin Ayvansarâyî, Mecmuâ-i Tevârih, haz. Fahri Ç. Derin, Vahid Çabuk, İstanbul, Edebiyat Fakültesi Basımevi, 1985.

Nevizade Atâi, Şakaik-i Nu'maniye ve Zeylleri, II, nşr. Abdülkadir Özcan, İstanbul, Çağn Yayınları, 1989.

Selânikî Mustafa Efendi, Tarih-i Selâniki, I, haz. Mehmet İpşirli, İstanbul, Edebiyat Fakültesi Basımevi, 1989.

Şeyhi Mehmed Efendi, Şakaik-i Nu'maniye ve Zeylleri, III, nşr. Abdülkadir Özcan, İstanbul, Çağrı Yayınları, 1989.

, Şakaik-i Nu'maniye ve Zeylleri, IV, nşr. Abdülkadir Özcan, İstanbul, Çağrı Yayınları, 1989.

\section{Ansiklopedi ve Lügatlar}

Devellioğlu, Ferit, Osmanlıca-Türkçe Ansiklopedik Lügat, Ankara, Aydın Kitabevi, 1995.

Eyice, Semavi, “İbrahim Paşa Külliyesi”, DİA, XXI, İstanbul, 2000.

Özcan, Abdülkadir, "Mehmed IV”, DIA, XXVIII, Ankara, 2003. 


\section{Araştırma ve İncelemeler}

Akyavaş, A. Ragıp, Âsitâne: Evvel Zaman İçinde İstanbul, Ankara, Türkiye Diyanet Vakfi Yayınları, 2008.

Alderson, A. Dolphin, Bütün Yönleriyle Osmanlı Hanedanı, çev. Şefaettin Severcan, İstanbul, Yenişafak, 1999.

Babinger, Franz, Osmanlı Tarih Yazarları ve Eserleri, çev. Coşkun Üçok, Ankara, Kültür ve Turizm Bakanlığı Yayınları, 1982.

Baltacı, Cahit, XV-XVI. Asırlarda Osmanlı Medreseleri, İstanbul, Marmara Üniversitesi İlahiyat Fakültesi Vakfı Yayınları, 2005.

David, Geza “Budin”, DIA, VI, İstanbul 1992.

Emecen, Feridun, “Selim II”, DİA, XXXVI, İstanbul, 2009.

Ertuğ Tarım, Zeynep, XVI. Yüzyll Osmanlı Devleti'nde Cülûs ve Cenaze Törenleri, Ankara, Kültür Bakanlığı Yayınları, 1999.

Erünsal, E. İsmail, Türk Kütüphaneleri Tarihi: Kuruluştan Tanzimat'a kadar Osmanlı Vakıf Kütüphaneleri, Ankara, Türk Tarih Kurumu Yayınları Atatürk Kültür Merkezi Yayını, 1988.

Eyice, Semavi, “Eyüp'de Zal Mahmud Paşa Camii”, Eyüp Sultan Sempozyumu V Tebliğler, İstanbul, Elma Matbaac1lık, 2002.

Gerlach, Stephan, Türkiye Günlüğü, I, çev. Türkis Noyan, ed. Kemal Beydilli, İstanbul, Kitap Yayınevi, 2007.

, Türkiye Günlüğü, II, çev. Türkis Noyan, ed. Kemal Beydilli, İstanbul, Kitap Yayınevi, 2007.

Gökbilgin, M. Tayyib, XV. ve XVI. Asırlarda Edirne ve Paşa Livası, VakıflarMülkler- Mukataalar, İstanbul, İşaret Yayınları, 2007.

Güler, Mustafa, "Şah Sultan ile Zal Mahmud Paşa Vakfiyesi”, Eyüp Sultan Seтроzуити V Tebliğler, İstanbul, Eyüp Belediyesi Kültür Yayınları, 2002.

Gülsoy, Ufuk, vd., Bir Medeniyetin İzdüşümü Vakıflar, İstanbul, Vakıflar Genel Müdürlüğü Yayınları, 2012.

Kahraman, Betül, "Vakfiyesi Işı̆̆ında Şah Sultan ve Zal Mahmud Paşa Külliyesi Cami Medrese, Türbe ve Çeşmesi”, (Yayımlanmamış Yüksek Lisans Tezi), Fatih Sultan Mehmet Vakıf Üniversitesi Lisansüstü Eğitimi Enstitüsü, İstanbul, 2019.

Kolçak, Olcay, Adile Sultan, İstanbul, Kastaş Yayınevi, 2005. 
Kuran, Aptullah, “Zâl Mahmud Paşa Külliyesi”, Boğaziçi Üniversitesi Dergisi, I, İstanbul, 1973.

Kütükoğlu, Mübahat S., XX. Asra Erişen İstanbul Medreseleri, Ankara, Türk Tarih Kurumu Basımevi, 2000.

Paşaoğlu Derin, Derya “28957 No'lu İrade-i Dahiliye’ye göre Nogay Muhacirleri üzerine bir değerlendirme", Kültür Evreni, cilt 3, sayı 10, Ankara, 2011.

Peirce, P. Leslie, Harem-i Hümayun, Osmanlı Imparatorluğu'nda Hükümranlık ve Kadınlar, İstanbul, Tarih Vakfı Yurt Yayınları, 2016.

Saz, Leyla, Haremde Yaşam, haz. Sedat Demir, İstanbul, DBY Yayınları, 2012.

Sezer, Hamiyet, “1894 İstanbul Depremi Hakkımda Bir Rapor Üzerine İnceleme”, Ankara Üniversitesi Dil ve Tarih-Coğrafya Fakültesi Tarih Bölümü Tarih Araştırmaları Dergisi, sayı 29, cilt 18, Ankara, 1996.

Tektaş, Nazım, Muhteşem Süleyman'in Gözyaşlarl, Şehzade Mustafa ve Bayezid, İstanbul, Çatı Kitapları, 2012.

Turan, Şerafettin, Kanuni Süleyman Dönemi Taht Kavgaları, İstanbul, Bilgi Yayınevi, 1997.

Uluçay, M. Çağatay, Harem, İstanbul, Ötüken, 2011. , Padişahların Kadınları ve Kızları, İstanbul, Ötüken, 2012. 